\title{
A Review: Nanomaterials Applied in Graphene-Based Electrochemical Biosensors
}

\author{
Xiaorong Gan and Huimin Zhao* \\ Key Laboratory of Industrial Ecology and Environmental Engineering \\ (Ministry of Education, China), School of Environmental Science and Technology, \\ Dalian University of Technology, Dalian 116024, China
}

(Received August 8, 2014; accepted November 11, 2014)

Key words: graphene-based nanohybrids, electrochemical biosensor, functionalization

Owing to the outstanding conductivity and biocompatibility as well as numerous other fascinating properties of graphene, graphene-based nanohybrids have shown unparalleled superiorities in the field of electrochemical biosensors. We provide a general overview of recent advances and state-of-the-art works related to all types of nanomaterial, including noble metals, transition metals, organic and inorganic dyes, polymers, biomolecules, ionic liquids (ILs), and boronic acid derivatives, applied to functionalize graphene to construct electrochemical biosensors. We are highlighting here types of functionalization, assembly procedures, roles of nanomaterial, and assay strategies. Finally, some future perspectives and possible research directions are also discussed.

\section{Introduction}

Graphene, a two-dimensional form of carbon atoms with a hexagonal lattice structure, ${ }^{(1)}$ is the thinnest material with a thickness of $0.35 \mathrm{~nm}$ to date among all the known materials. ${ }^{(2)}$ Graphene is also the fundamental building block of graphitic materials such as fullerenes, carbon nanotubes, and graphite. ${ }^{(3,4)}$ Its unique configuration and structure determine a number of exotic properties, ${ }^{(5)}$ such as high surface area $\left(2600 \mathrm{~m}^{2} \mathrm{~g}^{-1}\right),{ }^{(6)}$ mechanical strength (breaking strength $\sim 40 \mathrm{~N} \mathrm{~m}^{-1}$, Young's modulus $\sim 1.0 \mathrm{TPa}),{ }^{(7)}$ outstanding heat conductivity $\left(5000 \mathrm{~W} \mathrm{~m}^{-1} \mathrm{~K}^{-1}\right),{ }^{(8)}$ exceptional eletronic conductivity (200000 $\mathrm{cm}^{2} \mathrm{~V}^{-1} \mathrm{~s}^{-1}$ at room temperature), ${ }^{(9)}$ weakly scattered $\left(\lambda_{\text {scattering }}>\right.$ $300 \mathrm{~nm}$ ) ballistic transport of its charge carriers at room temperature, ${ }^{(10,11)}$ a chemically and geometrically controllable band gap, ${ }^{(12,13)}$ and quantum Hall effect at room temperature. ${ }^{(14)}$ Ideally, to preserve its distinct properties, graphene should be narrowed to single or few-layer thickness. ${ }^{(15)}$ In general, the graphene used in electrochemical biosensors is a multilayer structure ( $\leq 10$ layers).

${ }^{*}$ Corresponding author: e-mail: zhaohuim@dlut.edu.cn 
Its many intriguing properties, such as excellent conductivity while electronically being a good low-noise material, exceptional biocompatibility, easy functionalization, and mass production, endow graphene and its related composites with promising potential applications to electrochemical biosensors. Moreover, other applications including, but not limited to, synthesizing nanoelectronics, ${ }^{(16)}$ high-frequency electronics, ${ }^{(17,18)}$ energy storage and conversion devices, ${ }^{(19,20)}$ field-emission displays, ${ }^{(21,22)}$ and transparent conductors ${ }^{(23)}$ are also proofs of their versatility.

However, some inherent disadvantages of pristine graphene, such as easy aggregation, poor solubility and/or processability, are the big obstacles to the various applications for electrochemical biosensors. ${ }^{(24)}$ Therefore, it is necessary to modify graphene so that the as-prepared multifunctional hybrid materials could take full advantage of the superior properties of graphene and its functionalizing materials. ${ }^{(25,26)}$ Furthermore, after modification, the as-synthesized hybrid materials could not only overcome the disadvantages of pristine graphene but also be endowed with new desirable properties. To date, the modified nanomaterials applicable to electrochemical biosensors mainly include noble metals, transition metals, organic and inorganic dyes, polymers, biomolecules, ionic liquids (ILs), and boronic acid derivatives, which will be discussed in detail as follows.

Despite the many review articles ${ }^{(27-32)}$ available on graphene-based electrochemical biosensors, most of them were introduced or classified according to performance, such as enzymatic sensors, DNA and protein sensors, genosensors, and immunosensors. Herein, a new angle will be attempted in this review, from which our effort and attention focus on summarizing and highlighting the categories of nanomaterials applied to functionalize graphene for electrochemical biosensors from the literature over the past years. In the case of the present articles, methods of graphene synthesis are briefly introduced in $\S$ 2 , followed by the basic construction and principle of biosensors and electrochemical biosensors in $\S 3$, and a detailed discussion on different types of nanomaterial-graphenebased electrodes for electrochemical biosensors. On the basis of these discussions, some future perspectives and possible research directions are suggested.

\section{Graphene Synthesis}

Different graphene synthesis methods largely affect the performance of graphenebased electrochemical biosensors. ${ }^{(33)}$ Herein, it is fairly necessary to briefly illustrate general synthesis methods in ongoing studies. Until now, there have been a dozen methods for preparing graphenes of different morphologies and qualities. In general, the methods include, but not limited to, mechanical exfoliation, liquid suspension of graphene oxide followed by chemical reduction, liquid-phase exfoliation, expitaxial growth by chemical vapor deposition on trasition metals, expitaxial growth by the thermal desorption of $\mathrm{Si}$ atoms from the $\mathrm{SiC}$ surface, solvothermal synthesis, and unzipping of carbon nanotubes. The pros and cons of these methods are shown in Table 1.

The specific descriptions concerning the synthesis of graphene have been published in many papers..$^{(1,5,41,42)}$ Considering impurity introduction, the number of sheet layers, cost, productivity and so forth, there is no perfect method of synthesizing graphene until 
Table 1

Comparisons of different methods for graphene production. Reproduce with permission. ${ }^{(34)}$

\begin{tabular}{|c|c|c|c|c|c|c|}
\hline & Quality & Cost & Number of layers & Throughout & Size of layers & Ref. \\
\hline Mechanical exfoliation & High & Low & $\begin{array}{l}\text { Single and } \\
\text { multiple }\end{array}$ & Low & $10 \mu \mathrm{m}$ & (10) \\
\hline $\begin{array}{l}\text { Liquid suspension of } \\
\text { graphene oxide followed } \\
\text { by chemical reduction }\end{array}$ & Low & Low & $\begin{array}{l}\text { Single and } \\
\text { multiple }\end{array}$ & High & $\begin{array}{l}\text { Several hundred } \\
\mathrm{nm}\end{array}$ & $(35)$ \\
\hline Liquid-phase exfoliation & High & Low & $\begin{array}{l}\text { Single and } \\
\text { multiple }\end{array}$ & High & $\begin{array}{l}\text { Tens of } \mu \mathrm{m} \text { to } \\
\text { much smaller } \\
\text { fragments }\end{array}$ & (36) \\
\hline $\begin{array}{l}\text { Expitaxial growth } \\
\text { by chemical vapor } \\
\text { deposition on trasition } \\
\text { metals }\end{array}$ & High & High & $\begin{array}{l}\text { Single and } \\
\text { multiple }\end{array}$ & Low & $>100 \mu \mathrm{m}$ & (37) \\
\hline $\begin{array}{l}\text { Expitaxial growth by } \\
\text { thermal desorption of } \\
\text { Si atoms from the } \mathrm{SiC} \\
\text { surface }\end{array}$ & High & High & $\begin{array}{l}\text { Single and } \\
\text { multiple }\end{array}$ & Low & $>50 \mu \mathrm{m}$ & $(38)$ \\
\hline Solvothermal synthesis & $\begin{array}{c}\text { Not } \\
\text { available }\end{array}$ & Low & $\begin{array}{l}\text { Single and } \\
\text { multiple }\end{array}$ & High & $\begin{array}{l}\text { Tens of } \mu \mathrm{m} \text { to } \\
\text { much smaller } \\
\text { fragments }\end{array}$ & (39) \\
\hline $\begin{array}{l}\text { Unzipping of carbon } \\
\text { nanotubes }\end{array}$ & Inferior & Low & $\begin{array}{l}\text { Single and } \\
\text { multiple }\end{array}$ & High & $\begin{array}{l}\text { Nano ribbon } \\
\text { with length of } \\
4 \mu \mathrm{m}\end{array}$ & $(40)$ \\
\hline
\end{tabular}

Copyright 2009, Elsevier B.V. All rights reserved.

now. In terms of applications in electrochemical biosensors, graphene produced by liquid suspension of graphene oxide followed by chemical reduction, generally called the reduced graphene oxide (RGO) process, is used most extensively. The RGO process generally includes three steps, namely, chemical oxidiation of graphite by a strong oxidant, exfoliation, and reduction. ${ }^{(41)}$ The graphene synthesized by the RGO process exhibits smaller sizes, more structural defects, and more functional groups than those synthesized by the other methods. ${ }^{(3,43)}$ Thereinto, the edge-effect sites could realize fast electron-transfer kinetics; ${ }^{(32)}$ the emerging chemical moieties, either hydrophilic or hydrophobic, would not only effectively prevent the aggregation of graphene sheets by strong polar-polar interactions or by their bulky size ${ }^{(43)}$ but also facilitate various functionalizations to enhance the biosensor performance. ${ }^{(4)}$ In contrast, expitaxial growth by chemical vapor deposition on trasition metals and unzipping of carbon nanotubes may produce graphene with metallic impurities; ${ }^{(45)}$ the remaining methods may decrease the catalytic reactivity of graphene owing to its large size. Therefore, the graphene synthesized by the RGO process is advantageous for electrochemical applications compared with those synthesized by the other methods. ${ }^{(46-49)}$ 


\section{Introduction of Biosensor and Electrochemical Biosensor}

According to a recently proposed definition from the International Union of Pure and Applied Chemistry, ${ }^{(50)}$ "A biosensor is a self-contained integrated device which is capable of providing specific quantitative or semi-quantitative analytical information using a biological recognition element (biochemical receptor) which is in direct spatial contact with a transducer element". There are two main parts of a biosensor, namely, a recognition element and a transducer (a detector device). Generally, on the basis of signal transduction, biosensors could be divided into four groups: ${ }^{(51)}$ optical, electrochemical (Fig. 1), mass-sensitive, and thermometric.

In recent years, the unprecedented interest in the development of analytical devices for the detection, quantification and monitoring of specific chemical species with trace residues has led to the emergence of biosensors. The main reasons are that some conventional methods, such as spectroanalysis, titration and mass spectrometry, are cumbersome and time-consuming, and hardly meet the urgent demand for reliable and accurate trace/ultratrace analyses in areas such as the food industry, clinical diagnoses, hygiene, environmental protection, drug development and forensics. ${ }^{(52)}$ In contrast, biosensors can take advantage of the exquisite sensitivity and specificity of biomoleculars in conjunction with physicochemical transducers to deliver complex bioanalytical measurements with simple, easy-to-use formats. Specific interactions between biorecognition elements and analysts, such as thymine- $\mathrm{Hg}^{2+}$-thymine $\left(\mathrm{T}-\mathrm{Hg}^{2+}-\mathrm{T}\right)^{(53)}$ and cytimidine- $\mathrm{Ag}^{+}$-cytimidine $\left(\mathrm{C}-\mathrm{Ag}^{+}-\mathrm{C}\right),{ }^{(54)}$ and the subtle changes of biorecognition elements after the interactions, such as structure switching in $\mathrm{DNA}^{(55)}$ or activity changes in enzymes, ${ }^{(56)}$ could guarantee the selectivity and sensitivity of biosensors. Zhang et al. ${ }^{(57)}$ used the single-strand DNA with four T-T mismatches of grafted graphene to hybridize with the probe DNA in the presence of $\mathrm{Hg}^{2+}$. The as-prepared biosensor

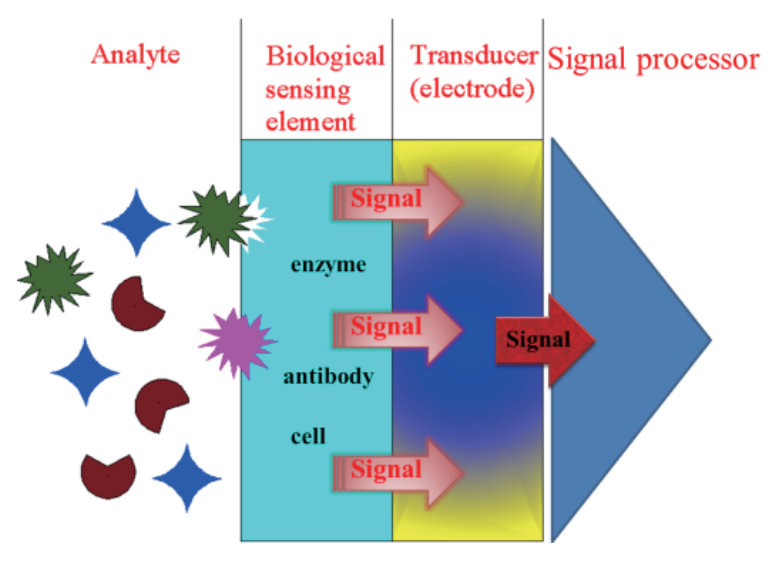

Fig. 1. (Color online) Schematic of an electrochemical biosensor. 
showed a high selectivity to $\mathrm{Hg}^{2+}$ and a low detection limit of $5 \mathrm{nM}$. Guo et al. ${ }^{(44)}$ designed an electrochemical immunosensor to detect carbohydrate antigen 199 on the basis of antibody-antigen interactions. Xu et al. ${ }^{(58)}$ used the inhibitory effect between an enzyme and its analyte to construct a biosensor that selectively detects Forchlorfenuron.

Until now, in the case of graphene, electrochemical biosensors account for most of the biosensors (Fig. 2), and have the greatest potential impact in the areas of healthcare, environmental monitoring, food packaging and many other applications owing to their high sensitivity and selectivity, simple instrumentation, fast response time, low production cost as well as real-time detection under in situ condition. ${ }^{(59)}$

In general, electrochemical biosensors are used to detect the change in current (amperometry and voltammetry), voltage (potentiometry), impedance or conductance resulting from a chemical reaction. ${ }^{(59,60)}$ With respect to the detected parameters, electrochemical biosensors can be divided into amperometric/voltammetric, potentiometric, impedance and conductometric. Many strategies applied in biosensors, such as enzyme amplification, ${ }^{(61)}$ nanomaterial amplification, ${ }^{(62)}$ specific interaction between an antibody and an antigen, ${ }^{(44)}$ and DNA structure switching, ${ }^{(55)}$ could also be adaptive to electrochemical biosensors. Zhang et al. ${ }^{(61)}$ used $\mathrm{T}-\mathrm{Hg}^{2+}-\mathrm{T}$ interaction and streptavidin-horseradish peroxidase enzymatic signal amplification to construct a highly sensitive and selective electrochemical DNA sensor for $\mathrm{Hg}^{2+}$ detection. Kong et al. ${ }^{(62)}$ utilized $\mathrm{T}-\mathrm{Hg}^{2+}-\mathrm{T}$ interaction and $\mathrm{Au}$ nanoparticle-functionalized reporter DNA as a signal amplifier to construct an ultrasensitive and highly selective electrochemical biosensor for $\mathrm{Hg}^{2+}$ detection. This biosensor had a detection range from $1 \mathrm{nM}$ to $0.1 \mathrm{mM}$ and a detection limit of $0.5 \mathrm{nM} \mathrm{Hg}^{2+}$.

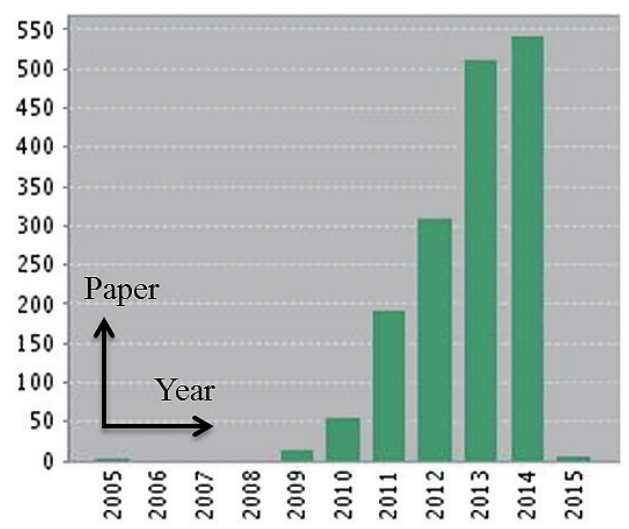

(a)

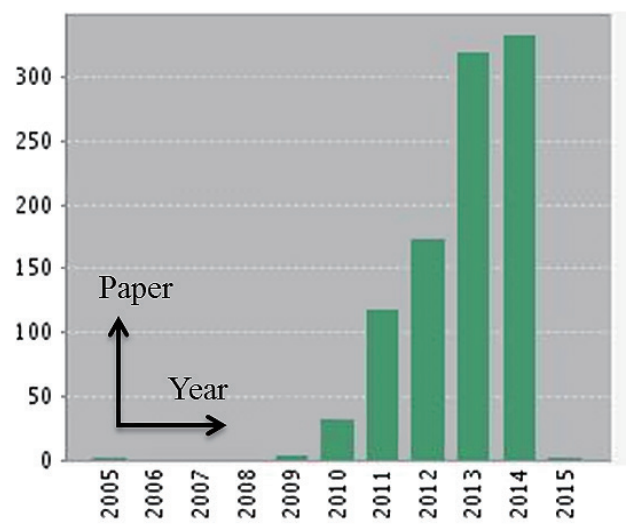

(b)

Fig. 2. (Color online) Published papers about (a) graphene-based biosensors and (b) graphenebased electrochemical biosensors from 2005 to 2015 (from Web of Science). 


\section{Graphene-Based Nanohybrids in Electrochemical Biosensor Applications}

With the advancement of nanotechnology and nanoscience, a variety of nanomaterials with different physicochemical characteristics could be controllably prepared, paving a bright way for multidisciplinary studies, particularly in biology, materials and chemistry. Since the fundamental processes of life occur at the nanoscale, electrochemical biosensors based on nanohybrids can leverage principles and materials common to biological systems. ${ }^{(63)}$ Moreover, nanoelectrodes have many merits, such as reduction in the Ohmic drop distortion and double-layer capacitances, an increase in the number of loading biological recognition elements owing to their larger specific surface area, being applied even in poorly conducting media, and an increase in the rate of mass transport. ${ }^{(59)}$ Consequently, nano-biomaterials could realize the manipulations and exploitations of biomolecules on the nanoscale and could widely be applied in transistors, gas sensors, catalysts as well as electronic and optical devices including biosensors and biochips. ${ }^{(59)}$

Nowadays, graphene undoubtedly has been a "rising star" in the field of electrochemical biosensors, owing to its high conductivity, low background current, wide potential window, chemical inertness, and suitability for various modes of sensing and detection. To further expand and optimize the use of graphene in electrochemistry and bio-nanotechnology, it is necessary to functionalize graphene. In the following sections, we will successively introduce a series of graphene nanomaterials, including graphene-noble metal or graphene-transition metal, graphene-metal oxide or graphene-semiconductor, grapheneinorganic dye, graphene-polymer, graphene-organic dye, graphene-biomolecule, and graphene-other nanohybrid materials for electrochemical biosensors.

\section{Graphene-Inorganic Nanohybrid Materials for Electrochemical Biosensor}

\subsection{Graphene-noble metal or graphene-transition metal nanohybrids as electrode materials}

It is well known that noble metals, such as $\mathrm{Au},{ }^{(64)} \mathrm{Ag},{ }^{(65)} \mathrm{Pt},{ }^{(66)} \mathrm{Pd},{ }^{(67)}$ and $\mathrm{Rh}$, ${ }^{(68)}$ exhibit outstanding conductivity and robust catalytic activity beneficial for promising applications in electrochemical biosensors. ${ }^{(69,70)}$ Of note, in addition to these excellent bulk properties, nanoscale noble metals have high surface-to-volume ratio and high surface energy to provide a larger amount of loading of bioelements than their bulk counterparts. Furthermore, nanoscale noble metals could provide a suitable microenvironment for biomolecule immobilization while retaining their biological activity and achieve fast signal transduction and amplification when involved in biorecognition events by conjugating with various biomolecules, chemical labels and other nanomaterials. ${ }^{(70,71)}$ In graphene-based electrochemical biosensors, nanoscale noble metals could effectively prevent the aggregation of graphene and facilitate electron transfer by acting as "electronic wires" to shorten the electron transfer distance between the immobilized biological recognition element and the electrode surface. ${ }^{72)}$ Therefore, noble metal nanomaterials have been widely used for the construction of electrochemical biosensors to enhance analytical performance. Among the noble metal nanomaterials, 
Au-based electrochemical biosensors have been investigated most extensively and comprehensively as shown by a number of good reviews. ${ }^{(64,73)}$

In this section, the nanohybrid electrodes of graphene modified by different noble metals for electrochemical biosensors are discussed. For example, Zhang and Jing ${ }^{(74)}$ immobilized RGO sheets decorated with gold nanoparticles (AuNPs) on a glass carbon electrode (GCE). As the peak currents of adriamycin are linear with the concentration of complementary DNA, the AuNPs/RGO/GCE-based electrochemical biosensor could successfully distinguish the one-base mismatched target DNA from the threebase mismatched and complementary sequence target DNAs. The as-prepared device had a detection range from $1.0 \times 10^{-8}$ to $1.0 \times 10^{-13} \mathrm{~mol} \mathrm{dm}^{-3}$ and a detection limit of $3.5 \times 10^{-14} \mathrm{~mol} \mathrm{dm}^{-3}$. Furthermore, a Au-graphene nanohybrid electrode was employed to detect $\mathrm{NO},{ }^{(75)} \mathrm{H}_{2} \mathrm{O}_{2},{ }^{(76)}$ and para-nitrophenol, ${ }^{(77)}$ and displayed remarkable electrocatalytic activity. Guo et al. ${ }^{(78)}$ showed that a Pt NP ensemble-on-graphenemodified GCE (PNEGHNs/GCE) has more favorable electron transfer kinetics enhancing electrochemical reactivity than pristine graphene alone, which provided a more robust and advanced hybrid electrode material for sensing small molecules (Fig. 3). Zeng et al. ${ }^{(79)}$ used chitosan to improve the solubility and dispersibility of graphene and constructed palladium nanoparticles (PdNPs)/chitosan-grafted graphene electrochemical biosensors for detecting glucose. Owing to the synergistic effect of PdNPs and graphene, the PdNPs/chitosan-graphene nanocomposite film displayed excellent electrocatalytic activity toward $\mathrm{H}_{2} \mathrm{O}_{2}$. Cao et al. ${ }^{(66)}$ investigated $\mathrm{Pt}, \mathrm{Pd}, \mathrm{Au}$, and their composites with different proportions to decorate graphene for the detection of cholesterol. It has been found that the Pt-Pd/chitosan-graphene/GCE electrode possessed the highest catalystic activity, a wide linear range from $2.2 \times 10^{-6}$ to $5.2 \times 10^{-4} \mathrm{M}$, and a low detection limit of 0.75 $\mu \mathrm{M}(S / N=3)$. The response time was less than $7 \mathrm{~s}$ and the Michaelis-Menten constant $\left(K_{\mathrm{m}}^{\mathrm{app}}\right)$ was $0.11 \mathrm{mM}$. The as-prepared biosensor also showed excellent reproducibility, stability, and high specificity to cholesterol even in the presence of ascorbic acid, uric acid, and glucose.

In addition to noble metal nanoparticles (NMNPs), extensive studies have been carried out to develop noble metals with other morphologies, such as nanoflower-like and nanowire, owing to their unique surface structure, high surface-to-volume ratio, and biologically compatible microenvironment, to functionalize graphene for electrochemical biosensors. Su et al. ${ }^{\left({ }^{0}\right)}$ fabricated a gold nanoflower/thionine/DNA-functionalized graphene immunosensor. The as-prepared electrochemical biosensor took full advantage of the edge-current effect of gold nanoflowers and three-dimensional DNA networks for carrying a large number of biomolecules, resulting in clear signal amplification.

Compared with NMNPs, noble metal nanowires (NMNWs) are more stable and less vulnerable to suffer from dissolution, Ostwald ripening, and aggregation during the electrocatalytic process, which would considerably improve the stability of electrochemical biosensors. ${ }^{(81)}$ Of note, the electron transfer between NMNPs is realized by quantum tunneling because the intergranular contact of NMNPs is not good, which would inevitably cause strong intergrain potential barriers and Coulomb blockade effects. Consequently, the electron exchange is carried out only between NMNPs and the matrix on the electrode surface; under the same condition, the device constructed 


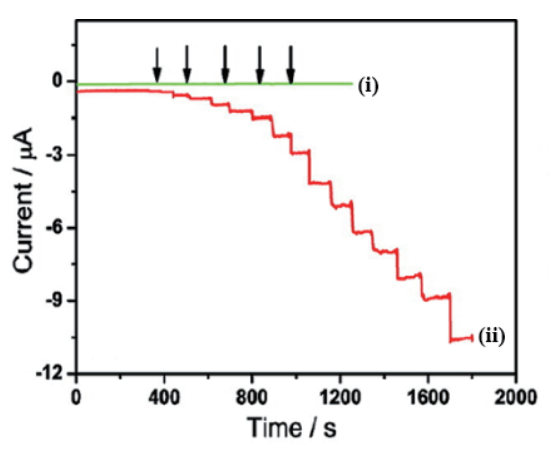

(a)

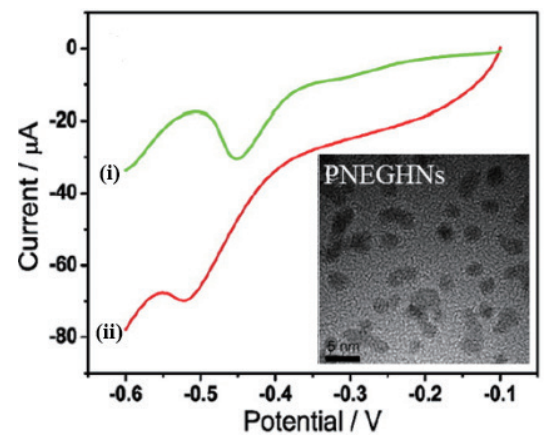

(d)

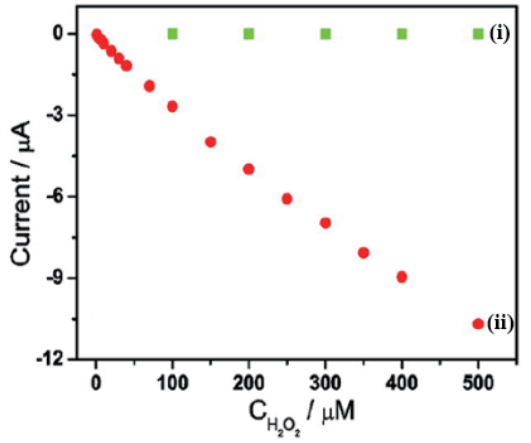

(b)

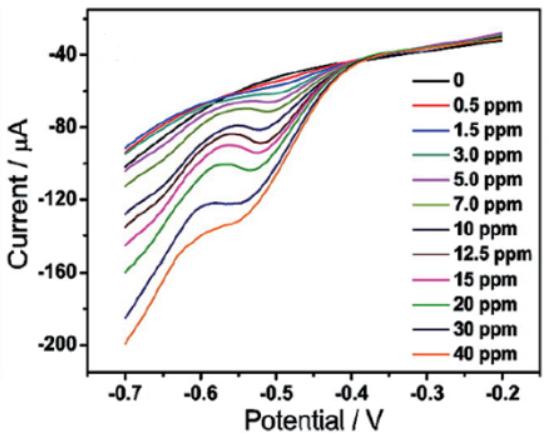

(e)

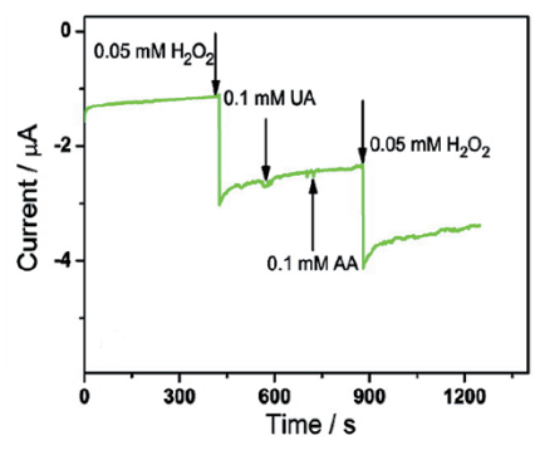

(c)

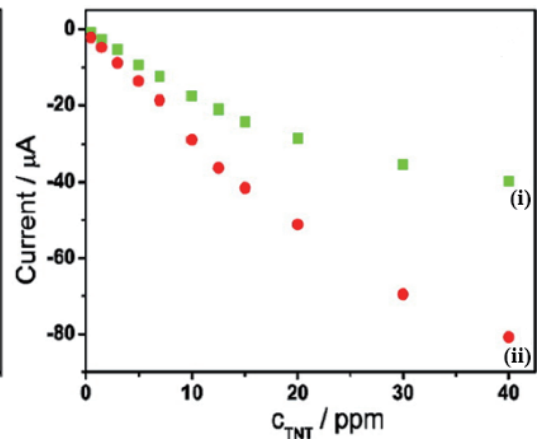

(f)

Fig. 3. (Color online) (a) Current-time recordings for successive additions of $\mathrm{H}_{2} \mathrm{O}_{2}$ at the (i) graphenes/GCE and (ii) PNEGHNs/GCE measured at $0 \mathrm{~V}$. (b) Plot of current of $\mathrm{H}_{2} \mathrm{O}_{2}$ vs its concentrations. (c) Current responses of the PNEGHNs/GCE to the sequential additions of 0.05 $\mathrm{mM} \mathrm{H}_{2} \mathrm{O}_{2}, 0.1 \mathrm{mM}$ ascorbic acid (AA), and $0.1 \mathrm{mM}$ uric acid (UA) into $0.1 \mathrm{M}$ phosphate-buffered saline (PBS). (d) Anodic stripping voltammetry (ASV) curves of (i) GNs/GCE and (ii) PNEGHNs/ GCE in a PBS (pH 9.4) in the presence of $10 \mathrm{ppm}$ 2,4,6-trinitrotoluene (TNT) at the scan rate of 50 $\mathrm{mV} / \mathrm{s}$. (e) ASV curve of PNEGHNs/GCE in a PBS ( $\mathrm{pH} 9.4)$ in the presence of TNT with different concentrations at the scan rate of $50 \mathrm{mV} / \mathrm{s}$. (f) Plot of currents of TNT vs its concentrations obtained at (i) GNs/GCE and (ii) PNEGHNs/GCE; the inset shows TEM image of PNEGHNs. ${ }^{(78)}$ Reproduce with permission. Copyright 2010, American Chemical Society.

by NMNPs would have a lower conductivity than a thin film or NMNWs. Inversely, NMNWs, particularly ultrathin NMNWs, could show a relatively high signal-to-noise ratio $^{(82)}$ and excellent conductivity owing to high aspect ratio and ballistic electron transport. ${ }^{(83)}$ Furthermore, NMNWs have a large adsorption surface, high electrical conductivity and a smaller diffusion time, which endow a higher capture efficiency and a faster response time to analytes. ${ }^{(84)}$ More importantly, networklike nanowires could 
absorb a large number of biomolecules with different sizes under the condition that retains the bioactivity only by adjusting the nanowire density. Currently, nanowires and metal networks have been successfully synthesized by various methods. ${ }^{(85,86)}$ However, for electrochemical biosensors, the reported studies are solely narrowed to pristine $\mathrm{Au}$ nanowire ${ }^{(85,87)}$ or Ag nanowire-graphene biosensors, ${ }^{(88,89)}$ even if there should be worthy of more attention for this field.

In addition to noble metals, interestingly, some transition metal hybrids, such as $\mathrm{Ni}$ and Ni-based materials, ${ }^{(90)}$ have been extensively investigated for the electrocatalytic oxidation of glucose, since they could considerably decrease the cost of glucose biosensors. For instance, Zhang et al. ${ }^{(91)}$ synthesized an RGO-nickel nanoparticle composite (RGO-Ni NPs) by either electrochemical reduction or electrodeposition for the nonenzymatic detection of glucose. The RGO-Ni NPs/GCE-based electrochemical biosensor showed good sensitivity, stability, and a low detection limit of $0.1 \mu \mathrm{M}$ with a linear range from $2 \mu \mathrm{M}$ to $2.1 \mathrm{mM}(r=0.996)$.

Considering the significance of conductivity, nanodimensional noble metals will surely play a critical role in the future. Hence, an enormous amount of effort is needed to explore novel structures or functional surfaces to further enhance the performance of electrochemical biosensors.

\subsection{Graphene-metal oxide or graphene-semiconductor nanohybrids as electrode materials}

Nanostructural metal oxides/semiconductors were extensively applied to energy and environment fields owing to their high surface area, nontoxicity, good biocompatibility, catalytic activity, and chemical stability.(92,93) Metal oxides generally have poor electrical conductivity, but decorating graphene materials with them would decrease the overpotential and increase the current density. In particular, nanostructural metal oxides (NMOs) elicited much interest owing to their superior biocompatibility, high surfaceto-volume ratio, high surface reaction activity, enhanced electron-transfer kinetics, and strong adsorption capability. ${ }^{(93)}$ Moreover, NMOs could provide a biocompatible electroactive surface beneficial for immobilizing biomolecules or a wealth of desirable functional groups, which further enhance the ability of biological recognition events. Therefore, NMOs are surely promising candidates for modifying graphene and constructing graphene-based electrochemical biosensors to accurately monitor and deeply understand interfacing biological recognition events for medicine diagnostic.

Among the various nanostructural metal oxides, $\mathrm{SnO}_{2},{ }^{(94)} \mathrm{TiO}_{2},{ }^{(95,96)} \mathrm{WO}_{3},{ }^{(97)} \mathrm{ZnO}$, ${ }^{(98)}$ $\mathrm{Fe}_{3} \mathrm{O}_{4},{ }^{(99)} \mathrm{In}_{2} \mathrm{O}_{3},{ }^{(100)} \mathrm{MnO}_{2},{ }^{(101)} \mathrm{Al}_{2} \mathrm{O}_{3},{ }^{(102)} \mathrm{Co}_{3} \mathrm{O}_{4},{ }^{(103)} \mathrm{NiO},{ }^{(104)}$ and $\mathrm{CuO} / \mathrm{Cu}_{2} \mathrm{O}^{(105,106)}$ have been constructed for biosensors. Generally, most of them were combined with noble metals $^{(107)}$ or other metal oxides ${ }^{(108)}$ in biosensor applications. However, the combination of metal oxides and graphene applied in the field of electrochemical biosensors has rarely been reported, except for a few metal oxides. Liu et al. ${ }^{(109)}$ modified a GCE with $\mathrm{Cu}_{2} \mathrm{O}$ nanocubes wrapped with graphene nanosheets for the detection of glucose and $\mathrm{H}_{2} \mathrm{O}_{2}$. Compared with bare GCE and $\mathrm{Cu}_{2} \mathrm{O} / \mathrm{GCE}$, the as-prepared biosensor showed higher stability, sensivity and selectivity upon sensing glucose and $\mathrm{H}_{2} \mathrm{O}_{2}$. The biosensor sensed glucose with a linear response from 0.3 to $3.3 \mathrm{mM}$ and a detection limit of $3.3 \mu \mathrm{M}(\mathrm{S} / \mathrm{N}$ 
= 3), and measured $\mathrm{H}_{2} \mathrm{O}_{2}$ with a linear response from 0.3 to $7.8 \mathrm{mM}$ and a detection limit of $20.8 \mu \mathrm{M}$. Xu et al. ${ }^{(106)}$ also investigated three methods, namely, physical adsorption, in situ reduction, and one-pot synthesis, to fabricate cuprous oxide- $\mathrm{RGO}\left(\mathrm{Cu}_{2} \mathrm{O}-\mathrm{RGO}\right)$ nanocomposites, and their effects on the catalytic reduction of $\mathrm{H}_{2} \mathrm{O}_{2}$. The results showed that physical adsorption was better than the other two methods with a slight advantage. The introduction of graphene could clearly improve the catalysis of $\mathrm{Cu}_{2} \mathrm{O}$ nanoparticles for the reduction of $\mathrm{H}_{2} \mathrm{O}_{2}$, while preventing the biosensor from corrosion. The asprepared biosensor exhibited a wider linear range from 0.03 to $12.8 \mathrm{mM}$, a higher sensitivity $\left(19.5 \mu \mathrm{A} \mathrm{m}^{-1} \mathrm{M}^{-1}\right)$ and a higher stability than the $\mathrm{Cu}_{2} \mathrm{O}$-based sensor for the accurate detection of $\mathrm{H}_{2} \mathrm{O}_{2}$.

In addition, $\mathrm{Hsu}$ et al. ${ }^{(110)}$ investigated the $\mathrm{CuO} /$ graphene-modified $\mathrm{GCE}$ and the $\mathrm{CuO} /$ graphene-modified screen-printed carbon electrode $(\mathrm{SPCE})^{(105)}$ for the nonenzymatic glucose sensor. Because of the larger roughness of the SPCE electrode and the flow injection analysis technology, the latter showed a higher sensitivity and a lower detection limit.

In enzyme biosensors, nanosize $\mathrm{ZnO}$ also has attracted considerable attention owing to its stable chemical and physical characteristics, good biocompatibility, high surface activity, and rapid electron communication features. ${ }^{(111)}$ Xie et al..$^{(112)}$ took advantage of the synergistic effects of carbon-based materials and metal nanoparticles or metal oxide to synthesize AuNPs/flower like zinc oxide/graphene (AuNPs/ZnO/graphene) composites to modify GCE. Afterwards, the electrode was immobilized with hemoglobin to detect $\mathrm{H}_{2} \mathrm{O}_{2}$, which revealed high selectivity, acceptable stability, good reproducibility, and repeatability along with excellent conductivity. Additionally, nanosheet-based $\mathrm{ZnO}$ microspheres with porous nanostructures were more effective in facilitating the electron transfer and showed a higher immobilized enzyme concentration than solid $\mathrm{ZnO}$ microspheres. ${ }^{(111)} \mathrm{Xu}$ et al. ${ }^{(113)}$ used hemoglobin entrapped in graphene and $\mathrm{ZnO}$ nanosphere composite film as an electrode to detect the performance of $\mathrm{H}_{2} \mathrm{O}_{2}$ reduction. The as-prepared electrochemical biosensor showed a linear range from $1.8 \mu \mathrm{M}$ to 2.3 $\mathrm{mM}$, with a detection limit of $0.6 \mu \mathrm{M}(S / N=3)$ and a Michaelis-Menten constant of 1.46 $\mathrm{mM}$. The phenomenon suggested that the graphene- $\mathrm{ZnO}$ nanosphere thin film could provide a compatible microenvironment for enhancing hemoglobin immobilization and absorption.

In addition, as a wide-band-gap semiconductor, $\mathrm{SnO}_{2}$ has opened a myriad of applications such as solar cells, ${ }^{(114)}$ electrochemistry sensors ${ }^{(115)}$ and biosensors. ${ }^{(116)}$ It has been reported that the nanocomposites of $\mathrm{SnO}_{2}$ nanoparticles $\left(\mathrm{SnO}_{2} \mathrm{NPs}\right)$ and carbon nanomaterials showed a higher electrochemical performance than the pristine $\mathrm{SnO}_{2}{ }^{(117)}$ Zhou et al. (118) combined the excellent film-forming ability and biocompatibility of chitosan with the chemical inertness and ideal conductivity of Nafion (NF) to design an acetylcholinesterase (AChE) electrochemical biosensor. The as-prepared electrode based on $\mathrm{SnO}_{2} \mathrm{NPs}$, carboxylic graphene (CGR), and an NF-modified glassy carbon electrode, namely, NF/AChE-chitosan/ $\mathrm{SnO}_{2} \mathrm{NPs}-\mathrm{CGR}-\mathrm{NF} / \mathrm{GCE}$, showed favorable affinity to acetylthiocholine chloride (ATCl) with a linear detection for methyl parathion from $10^{-13}$ to $10^{-10} \mathrm{M}$ and from $10^{-10}$ to $10^{-8} \mathrm{M}$, and for carbofuran from $10^{-12}$ to $10^{-10} \mathrm{M}$ and from $10^{-10}$ to $10^{-8} \mathrm{M}$. The detection limits of methyl parathion and carbofuran were $5 \times 10^{-14}$ and $5 \times 10^{-13} \mathrm{M}$, respectively (Fig. 4). 


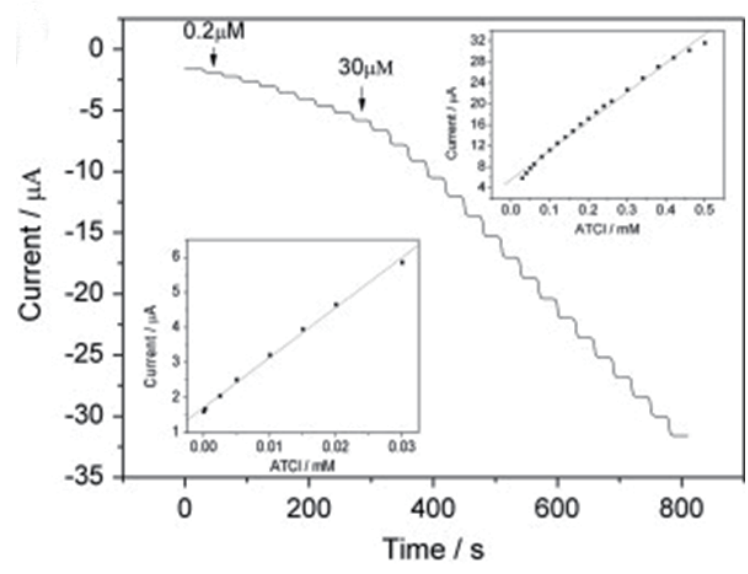

(a)

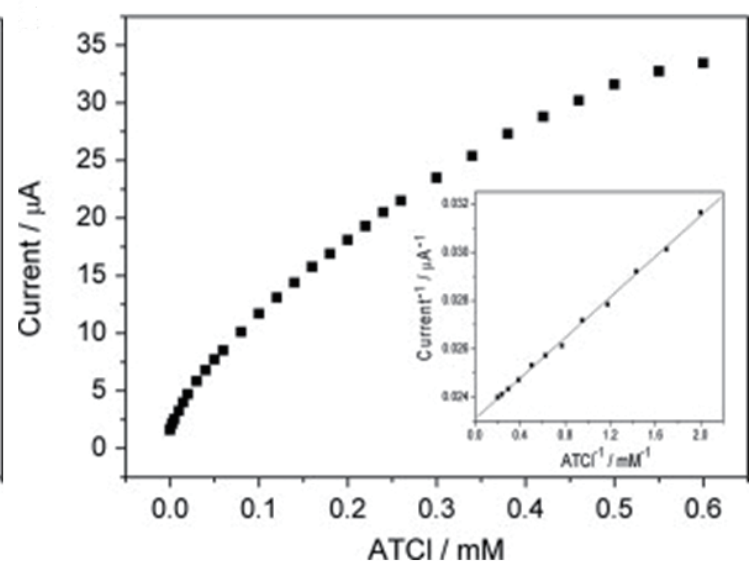

(b)

Fig. 4. (a) Typical current-time plot for the sensor on successive addition of stock ATCl to 0.1 M PBS; insets show the calibration curves for ATCl determination. (b) Calibration plot for the $\mathrm{ATCl}$ sensor; inset shows the Lineweaver-Burk plot of $1 / i_{\mathrm{ss}}$ vs $1 / C$. Reproduce with permission. ${ }^{(118)}$ Copyright 2013 Elsevier B.V. All rights reserved.

Similarly, as an excellent photoelectric material, $\mathrm{TiO}_{2}$ was also employed to construct the electrochemical biosensor to detect glucose, ${ }^{(119)} \mathrm{DNA},{ }^{(120)}$ paracetamol, ${ }^{(96)}$ carbaryl, ${ }^{(95)}$ and base pairs. ${ }^{(121)}$ Jang et al. ${ }^{(119)}$ studied $\mathrm{TiO}_{2}$-graphene nanocomposites as electrodes to detect glucose by the amperometric method. The biosensor exhibited the highest sensitivity at about $6.2 \mathrm{~mA} \mathrm{mM}{ }^{-1} \mathrm{~cm}^{-2}$ and a linear detection limit ranging from 0 to 8 $\mathrm{mM}$ at $-0.6 \mathrm{~V}$.

\subsection{Graphene-inorganic dye nanohybrids as electrode materials}

Until now, among all inorganic dyes, Prussian blue (PB) is the only compound combined with graphene that is broadly applied in electrochemical biosensors. As an artificial peroxidase, $\mathrm{PB}$ is a superior and selective electrocatalyst for hydrogen peroxide reduction, even in the presence of oxygen. Therefore, it is extensively applied in the construction of oxidase-enzyme-based biosensors for clinical, environmental and food analyses. ${ }^{(122)}$ Many PB-graphene-based electrochemical biosensors have been fabricated owing to their synergistic effect. Jiang et al. ${ }^{(123)}$ firstly electrodeposited PB onto a graphene matrix immobilized on GCE. The as-prepared electrochemical sensor showed excellent electrocatalytic activity toward both the reduction of hydrogen peroxide and the oxidation of hydrazine. Moreover, wide linear ranges of $10-1440 \mu \mathrm{M}$ at $0.0 \mathrm{~V}$ to $\mathrm{H}_{2} \mathrm{O}_{2}$ and $10-3000 \mu \mathrm{M}$ at $0.35 \mathrm{~V}$ to hydrazine were obtained. The detection limits of $\mathrm{H}_{2} \mathrm{O}_{2}$ and hydramine were 3 and $7 \mu \mathrm{M}$, respectively, and both showed a rapid response within $5 \mathrm{~s}$ to reach a $95 \%$ steady state. The same electrode material was synthesized by mixing ferric(III) chloride and potassium ferricyanide in the presence of graphene under ambient 
conditions to investigate the electrocatalytic behavior of $\mathrm{H}_{2} \mathrm{O}_{2}$. The detection limit in the linear range of $0.02-0.2 \mathrm{mM}$ was $1.9 \mu \mathrm{M}$ with a sensitivity of $196.6 \mu \mathrm{A} \mathrm{mM}^{-1} \mathrm{~cm}^{-2}{ }^{(124)}$

In addition, $\mathrm{PB}$ can also be used for the construction of DNA-based biosensors. Bo et al. ${ }^{(125)}$ investigated the direct electrochemical behavior of single-stranded DNA on chitosan and PB-modified graphene paste electrodes when employed to detect the target DNA hybridization. The as-synthesized biosensor displayed a wide linear range from 2.12 $\times 10^{-8}$ to $2.12 \times 10^{-11} \mathrm{M}$, a low detection limit of $1.58 \times 10^{-11} \mathrm{M}$ and good reproduction with the standard deviation of $2.83 \%(n=4)$ after one week. The results confirmed that the use of PB could improve the performance of the modified electrodes, and that the presence of graphene was beneficial for improving the sensitivity of the electrochemical biosensor. However, PB-modified electrodes would be disrupted after a few potential scans at neutral $\mathrm{pH} .{ }^{(126)}$

\section{Graphene-Organic Nanohybrids for Electrochemical Biosensor}

\subsection{Graphene-polymer nanohybrids as electrode materials}

Some polymers, such as conducting polymers, chitosan, and NF, play different but critical roles as either some type of additive or main component to construct electrochemical biosensors. Combining the polymers with graphene is mainly driven by the possibility of improving the solubility/processability of the graphene in either water or organic solvents while preventing the stacking of graphene from generating graphite. ${ }^{(127)}$ Consequently, to a large extent, it would enhance the sensitivity, selectivity and enlarge the number of analytes. To the best of our knowledge, among these polymers, conducting polymers account for the largest percentage owing to their versatility.

Conducting polymers are called "synthetic metals" because their electric, electronic, magnetic, and optical properties are similar to those of metals or semiconductors. ${ }^{(128)}$ Generally, according to the functions of conducting polymers in electrochemical biosensors, they could be classified into several types: receptors, transducers, immobilization matrices, and so forth. However, because conducting polymers are multifunctional materials, it is almost impossible to make a completely clear and definite separation in terms of their functions. To date, nanoconducting polymers, such as polypyrrole, polythiophene, poly(3,4-ethylenedioxythiophene), polycarbazole, polyaniline, polyphenol, poly(o-phenylenediamine), polyacetylene, polyfuran and their derivatives with or without being modified by other functional groups or other organic compounds, have been widely used to modify matrices or directly as electrode materials for constructing third-generation biosensors. ${ }^{(129,130)}$

According to published papers, ${ }^{(130,131)}$ polymer-based biosensors could detect various materials, such as gaseous analytes, ${ }^{(132)}$ organic molecules, ${ }^{(133)}$ and heavy metals. ${ }^{(134,135)}$ The sensitivity and selectivity of conducting-polymer-based electrochemical biosensors are primarily determined by the changes in specific properties before and after exposure to a test target molecule. In particular, polymer-modified carbon substrate electrodes designed through polymer screening could provide tremendous improvements in the sensitivity, selectivity, stability, and reproducibility of as-prepared biosensors. ${ }^{(136)}$ Liu et al.(137) combined graphene with polyaniline (PANI) to develop a label-free aptamer/ graphene-PANI/GCE-based electrochemical biosensor for dopamine (DA) determination. 
The electrochemical aptasensor showed a linear response to DA in the range of 0.007-90 nmol L $\mathrm{L}^{-1}$ and a detection limit of $0.00198 \mathrm{nmol} \mathrm{L}^{-1}(S / N=3)$. The enhanced electron transfer ability and high electrocatalytic activity are ascribed to the synergistic effect of graphene and PANI. Moreover, graphene-PANI nanocomposites have also been extensively applied to gas sensors and DNA biosensors. ${ }^{(138,139)}$

Similarly, Wei et al..$^{(140)}$ took advantage of the synergistic effect of graphene and thionine $(\mathrm{TH})$ to develop a novel label-free electrochemical immunosensor by immobilizing an anti- $\alpha$-fetoprotein antibody on a graphene sheet (GS) and a TH-modified glassy carbon electrode for the detection of $\alpha$-fetoprotein (AFP). The immunosensor exhibited high sensitivity, a wide linear range from 0.05 to $2.00 \mathrm{ng} \mathrm{mL}^{-1}$, a low detection limit of $5.77 \mathrm{pg} \mathrm{mL}^{-1}(S / N=3)$ and good long-term stability. Xing et al. ${ }^{(141)}$ prepared an imprinted electrochemical sensor based on polypyrrole-sulfonated graphene (PPySG)/hyaluronic acid-multiwalled carbon nanotubes (HA-MWCNTs) for the sensitive detection of tryptamine in food. It was suggested that the PPy-SG composite film showed improved conductivity and electrochemical performance characteristics. The sensor exhibited a linear range from $9.0 \times 10^{-8} \mathrm{~mol} \mathrm{~L}^{-1}$ to $7.0 \times 10^{-5} \mathrm{~mol} \mathrm{~L}^{-1}$ and a detection limit of $7.4 \times 10^{-8} \mathrm{~mol} \mathrm{~L}^{-1}(S / N=3)$.

Chitosan, a linear hydrophilic polysaccharide biopolymer obtained from the partial deacetylation of chitin, is the second most abundant natural polymer on Earth. ${ }^{(142)}$ It has been broadly utilized to immobilize matrices for biodevices owing to its high permeability toward water, excellent membrane-forming ability, good adhesion, and biocompatibility. ${ }^{(143,144)}$ In particular, in enzyme-based biosensors, it could offer a natural microenvironment for the enzyme and sufficient accessibility for electrons to shuttle between the enzyme and the electrode. ${ }^{(143)}$ Therefore, it is reasonable to speculate that the hydrophilicity and biocompatibility of graphene functionalized by chitosan could be largely improved compared with those of pristine graphene. Furthermore, a graphenechitosan nanocomposite film can effectively retain the bioactivity of recognition elements. In the case of graphene-chitosan nanohybrid-based electrochemical biosensors, numerous studies have been performed to investigate the direct electron transfer between the protein or enzyme and the electrode surface. Xu et al. ${ }^{(144)}$ fabricated a graphene and the chitosan composite film for immobilizing hemoglobin $(\mathrm{Hb})$ to detect $\mathrm{H}_{2} \mathrm{O}_{2}$ (Fig. 5). It was suggested that chitosan could offer good microenvironment to guarantee the activity of $\mathrm{Hb}$, and that the presence of graphene could considerably enhance the enzyme absorption and promote the direct electron transfer between redox enzymes and the electrode surface.

Kang et al. ${ }^{(143)}$ immobilized glucose oxidase (GOD) to graphene-chitosan nanocomposites on the surface of a GCE (GOD/graphene-chitosan/GCE) to detect glucose. The electrochemical biosensor exhibited a wide linearity range from $0.08 \mathrm{mM}$ to $12 \mathrm{mM}$ with a detection limit of $0.02 \mathrm{mM}$ and a high sensitivity of $37.93 \mu \mathrm{A} \mathrm{mM}^{-1}$ $\mathrm{cm}^{-2}$.

In summary, in most graphene-based electrochemical biosensors, chitosan was only considered as an additive to assist the formation of a biorecognition film and to improve the dispersibility of graphene and consequently to enhance the conductivity and stability of the biosensor. ${ }^{(144-148)}$ 


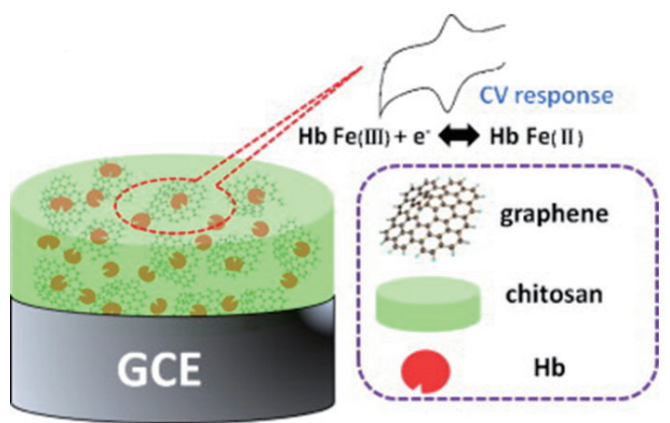

(a)

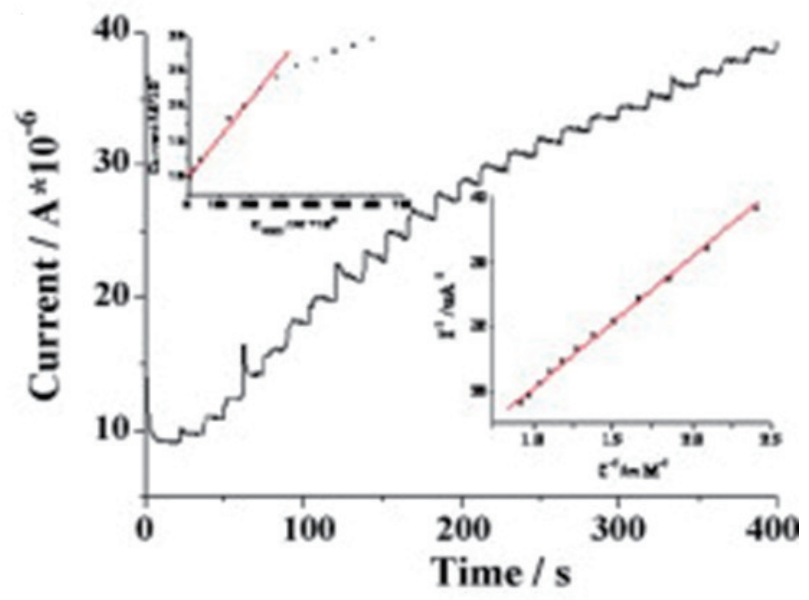

(b)

Fig. 5. (Color online) (a) Schematic of the construction of Hb-graphene-chitosan/GCE. (b) Amperometric response of $\mathrm{Hb}$-graphene-chitosan/GCE in $0.1 \mathrm{M} \mathrm{PBS}(\mathrm{pH} \mathrm{7.0)}$ ) at $-400 \mathrm{mV}$ upon successive additions of $\mathrm{H}_{2} \mathrm{O}_{2}$; insets show the calibration curve (top left) and corresponding Lineweaver-Burk plot (right side). Reproduce with permission. ${ }^{(144)}$ Copyright 2010 Elsevier B.V. All rights reserved.

$\mathrm{NF}$, as another polymer solution for the preparation of graphene-based electrodes, has been extensively used to immobilize enzymes on the electrode surface owing to its good biocompatibility, unique ion-exchange ability, thermal stability, mechanical strength, excellent film-forming ability, and antifouling properties. ${ }^{(149,150)}$ In particular, its strong antifouling properties would accelerate electron transfer between the recognition element and the electrode. ${ }^{(151)}$ Moreover, its excellent dispersion performance also effectively prevents the irreversible agglomeration or restacking of graphene through strong $\pi-\pi$ stacking and van der Waal's interaction. ${ }^{(152,153)}$

On the basis of that, Li et al. ${ }^{(154)}$ used an NF-graphene-modified GCE with a bismuth film to detect $\mathrm{Pb}^{2+}$ and $\mathrm{Cd}^{2+}$ by differential pulse anodic stripping voltammetry (DPASV). It was found that the as-prepared electrodes showed high sensitivity and excellent ability to reduce the interference of surfactants as a result of the synergistic effect of graphene and NF. On the other hand, NF-graphene/GCE electrodes displayed excellent electrocatalytic activity toward the oxidation of guanine and adenine owing to the clearly increased electrode effective surface area. ${ }^{(155)}$

\subsection{Graphene-organic dye nanohybrids as electrode materials}

In contrast to graphene-inorganic dyes, graphene-organic dye nanohybrids as electrode materials have relatively more potential in electrochemical biosensors. Therein, three types of organic dyes, including porphyrin, methylene blue (MB), and 
methylene green $(\mathrm{MG})$, which are most frequently used to construct electrochemical biosensors, would be discussed in detail.

Porphyrin could readily modify graphene through $\pi$ - $\pi$ interactions to render the nanohybrid materials with excellent specificity and conductivity. Tu et al. ${ }^{(156)}$ obtained a porphyrin/RGO-modified indium-tin-oxide (ITO) electrode to detect chlorite by electrocatalytic reduction. The device showed a good linear range from 0.5 to 50 $\mu \mathrm{mol} \mathrm{L} \mathrm{L}^{-1}$ and good reproducibility with a relative standard deviation of $4.6 \%$ after five determinations. Wu et al. ${ }^{(157)}$ prepared a water-soluble anion porphyrin/chemically reduced graphene-modified GCE for the detection of DA in human urine and serum samples. The as-formed biosensor with a detection limit of $0.01 \mu \mathrm{M}$ could accurately detect DA even in the presence of large amounts of ascorbic acid and uric acid. The phenomena should be attributed to the favorable electrostatic attraction and $\pi-\pi$ stacking between the positively charged DA and the negatively charged porphyrin-modified graphene. The acceptable relative standard derivation (relative standard deviation, $n=6$ ) and recovery certified its practicable application. Additionally, the graphene-porphyrin nanohybrid electrode could be applied to detect dissolved oxygen, ${ }^{(158)}$ DNA, ${ }^{(159)}$ and adenosine triphosphate (ATP) ${ }^{(160)}$ by taking advantage of the synergistic effect.

$\mathrm{MB}$, an organic dye that belongs to the phenothiazine family, has been widely exploited for DNA hybridization detection as an electrochemical indicator. ${ }^{(161-164)}$ Nevertheless, research studies on MB-functionalized graphene in electrochemical biosensors are few. Among the reported research studies, synthesis strategies were largely developed on the basis of MB characteristics, such as good conductivity and the absence of the current peak in cyclic voltammograms of GS. ${ }^{(165)}$ Mao et al..$^{(165)}$ used chitosan as a dispersant to fabricate a GS-MB nanocomposite film stably immobilized onto the surface of a GCE. Afterwards, the antibody of the prostate-specific antigen (PSA) was conjugated onto the modified electrode to detect PSA. The detection limit and linear range were $13 \mathrm{pg} \mathrm{mL}^{-1}$ and $0.05-5.00 \mathrm{ng} \mathrm{mL}^{-1}$, respectively. Ferreira et al. ${ }^{(166)}$ designed a DNA/graphene/MB-composite-immobilized GCE to detect $\beta$-nicotinamide adenine dinucleotide (NADH). It was found that MB was more effectively immobilized when DNA was used as a platform for the entrapment of MB on graphene. Accordingly, the presence of DNA prevented the significant signal loss and enhanced the stability of biosensors. Under optimized conditions, a linear response range from $10 \mu \mathrm{mol} \mathrm{L} \mathrm{L}^{-1}$ to 1.50 mmol L ${ }^{-1}$ and a detection limit of $1.0 \mu \mathrm{mol} \mathrm{L}^{-1}$ were obtained with a sensitivity of 12.75 $\mu \mathrm{A} \mathrm{L} \mathrm{mol}{ }^{-1}$.

MG is a heterocyclic aromatic chemical compound similar to methylene blue. Furthermore, MG is a water-soluble molecule with a positive charge and good electrochemical properties. Therefore, it has been widely used for basic electrochemical studies and applications, such as biosensors and biofuel cells. ${ }^{(167)}$ Liu et al. ${ }^{(167)}$ investigated the electrochemical behavior of NADH on MG-graphene/GCE. The results showed that the presence of MG could endow graphene with electroactive properties and improve both the dispersity and electrochemical property of graphene through a watersoluble electroactive aromatic molecule through $\pi-\pi$ interaction. The as-formed electrode largely accelerated electron transfer kinetics and lowered the oxidation overpotential of $\mathrm{NADH}$. 


\subsection{Graphene-biomolecule nanohybrids as electrode materials}

To improve the selectivity, sensitivity, and specificity of biosensors in affinity assays, some large biomolecules, such as enzymes, ${ }^{(168)}$ aptamers (DNA/RNA), ${ }^{(169,170)}$ and cells, ${ }^{\left({ }^{(82)}\right.}$ have been selected as recognition elements to obtain functional graphene electrodes. The molecule-beacon architectures can be exploited to monitor the changes in conformation, microcurrent, and micropotential.

In the case of the as-prepared electrodes, in addition to inherent characteristics, extraordinary molecule structures were extensively applied to immobilize other biomolecules. For instance, the three-dimensional structured DNA is beneficial for immobilizing enzymes or other molecules through intercalative and electrostatic binding. ${ }^{(171)}$ The cell surface could also be used to immobilize or recognize DNA. ${ }^{(172)}$ Herein, the advantages from both structure and function yield the synergistic effect. So far, among graphene-biomolecule nanohybrid-based electrochemical biosensors, the graphene-enzyme composites have been investigated most extensively as largescale commercialization has been realized for the enzyme biosensors. Currently, the electrochemical biosensors are commonly applied in food, ${ }^{(173)}$ medical, ${ }^{(168)}$ and environmental fields. ${ }^{(174)}$

$\mathrm{Wu}$ et $a$. $^{(175)}$ immobilized GOD on graphene/GCE to detect glucose based on the bioelectrocatalytic reduction of oxygen. The as-produced electrode (RG-GOD/ $\mathrm{GCE}$ ) witnessed the facile direct electron transfer from the redox sites of the enzyme to the electrode. Moreover, the electrochemical biosensor showed very good stability, reproducibility and high selectivity against DA, uric acid and ascorbic acid. The detection limit toward glucose was $1.85 \mathrm{~mA} \mathrm{Mm}^{-1} \mathrm{~cm}^{-2}$ in the linear range from 0.1 to 27 $\mathrm{mM}$. The graphene-metal oxide/semiconductor composite as the enzyme matrix could also realize direct electron transfer and superior sensitivity toward glucose. ${ }^{(176)}$ Similarly, the detection of organophosphate pesticides could be carried out by loading $\mathrm{AChE}^{(177)}$ and tyrosinase. ${ }^{(174)}$ Wang et al. ${ }^{(177)}$ utilized AChE-CdS-graphene-chitosan/GCE to detect the organophosphate carbaryl. The as-prepared biosensor showed high affinity to ATCl with a Michaelis-Menten constant $\left(K_{\mathrm{m}}\right)$ of $0.24 \mathrm{mM}$, good reproducibility, acceptable stability, and a reliable linear relationship between the inhibition and $\log$ [carbaryl] from $2 \mathrm{ng} \mathrm{mL} L^{-1}$ up to $2 \mathrm{~mL}^{-1}$ and a detection limit of $0.7 \mathrm{ng} \mathrm{mL}^{-1}$. The results are attributed to the synergistic effect of graphene and CdS nanocrystals.

Recently, aptamers, which are artificial, short, and single-stranded DNA/RNA oligonucleotides, have also attracted intense interest owing to their ability to bind small molecules, proteins, or even cells with high specificity and affinity. ${ }^{(171,178)}$ In comparison with protein-based antibodies or enzymes, aptamer-based biosensors show unprecedented advantages. ${ }^{(171,179)}$ Feng et al. ${ }^{(172)}$ immobilized aptamer AS1411 to functionalize graphene for the selective label-free detection of cancer cells. High binding affinity and specificity were realized via the conformational transition when the aptamer captured cancer cells. The as-prepared electrochemical sensor could distinguish label-free cancer cells from normal cells; moreover, it showed superior biocompatibility, regeneration, and selectivity toward four types of cancer cells by electrochemical impedance spectroscopy, and a low detection limit of one thousand cells. Because thymine-thymine (T-T) mismatches could selectively capture $\mathrm{Hg}^{2+}$ to form $\mathrm{T}-\mathrm{Hg}^{2+}-\mathrm{T}$ base pairs to detect heavy metal ions, ${ }^{(53)}$ Zhang et al. ${ }^{(57)}$ took advantage of $\left[\mathrm{Ru}\left(\mathrm{NH}_{3}\right)_{6}\right]^{3+}$ as an electroactive probe, firstly via the Michael 
addition reaction, to graft single-stranded probe DNA modified at the 5'-end with an alkylamino modifier $\left(\mathrm{NH}_{2}\right.$-ssDNA) on the RGO surface. Afterwards, nanohybrids of $\mathrm{NH}_{2}$-ssDNA-RGO were immobilized on the GCE and hybridized with 4-mis DNA to detect $\mathrm{Hg}^{2+}$. The results revealed that the proposed electrochemical biosensor had good selectivity for $\mathrm{Hg}^{2+}$ determination against other heavy metal ions in river water and a low detection limit of $5.0 \times 10^{-9} \mathrm{M}(S / N=3)$. In addition to the applications above, DNA was also combined with other graphene-based nanohybrids mentioned previously, such as graphene-metal oxide and graphene-conducting polymers, to detect various analytes.

More recently, studies on interfacing nanomaterials with biocomponents have become a hot topic in terms of detecting biocomponents or biological phenomena. ${ }^{(180)}$ The main reasons are that the interfaces generated between nanomaterials and the cell wall or membrane could lead to subtle changes in the microcurrent or micropotential when reacted with analytes. Owing to some unique properties of graphene beneficial for nanoscale electronic devices, graphene could provide a sensitive platform for interfacing with biological cells to detect intra- and extracellular phenomena. ${ }^{(181)}$

He et al. ${ }^{(182)}$ combined the obtained RGO with living neuroendocrine PC12 cells as a nanodevice (Fig. 6). The as-fabricated device was applied to detect the cellular secretion of catecholamine molecules (DA, epinephrine, and norepinephrine) by monitoring the

(a)

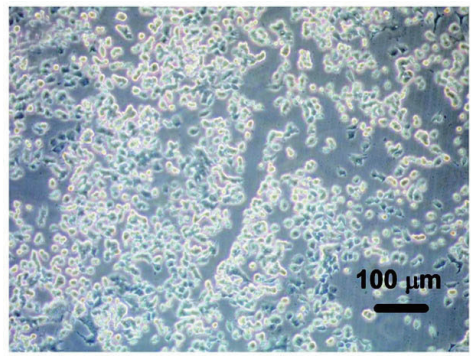

(b)

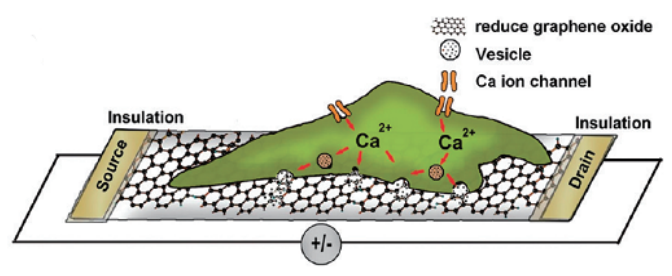

(c)

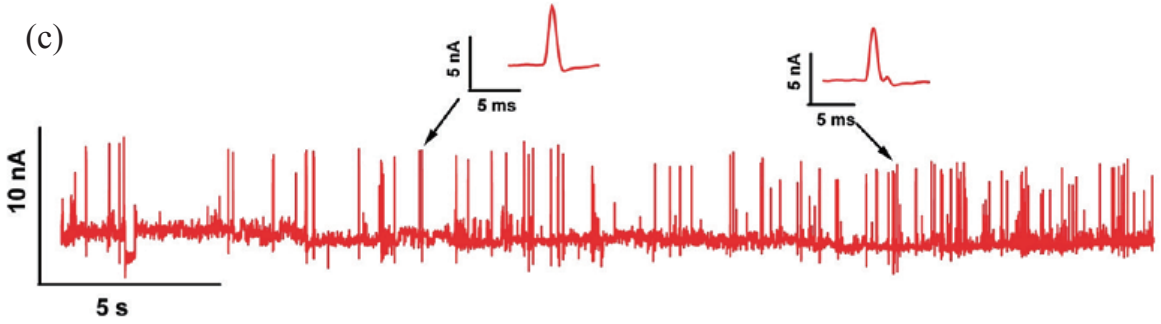

Fig. 6. (Color online) (a) Optical image of PC12 cells grown confluently on a poly-L-lysinecoated RGO device. (b) Schematic illustration of the interface between a PC12 cell and a RGO FET. (c) Real-time response of RGO to the vesicular secretion of catecholamines from PC12 cells stimulated by high- $\mathrm{K}^{+}$solution. $V_{\mathrm{ds}}=100 \mathrm{mV}$ and $V_{\mathrm{g}}=0 \mathrm{~V}$. The drain and source electrodes are 1 cm apart. Reproduce with permission. ${ }^{(182)}$ Copyright 2010, American Chemical Society. 
change in the potential of the cellular membrane interfaced with the underlying RGO. Their results suggest that the high uniformity of RGO patterns is crucial for achieving the reliable device performance in flexible nanoelectronics and bioelectronics.

Hess et al. ${ }^{(181)}$ synthesized graphene-based solution-gated field-effect transistors (G-SGFETs) to detect the change in the electrical potential (or "beating") of cardiomyocyte-like HL-1 cells. The device fabricated on flexible substrates exhibited a high signal-to-noise ratio $(>4)$, which could pave the way for a true breakthrough in the field of bioelectronics.

\section{Graphene-Other Nanohybrid for Electrochemical Biosensor}

Similar to the roles of polymers or dyes mentioned in the previous sections, some other materials, such as ILs and boronic acid derivatives, have been employed to prevent irreversible agglomeration and to guarantee the stability or catalytic activity of graphenebased electrochemical biosensors.

ILs have been widely used in enhancing the performance of the modified electrode as a binder for biosensors owing to their electrochemical stability, low background current, and biocompatibility. ${ }^{(183)}$ ILs in a previous work showed that they are effective solubilizing agents for graphene nanosheets via $\pi-\pi$ interactions and have improved sensitivity for the detection of various analytes, such as ethanol, ${ }^{(184)}$ glucose, ${ }^{(185)}$ and ascorbic acid. ${ }^{(186)}$ Shan et al. ${ }^{(184)}$ investigated the IL-graphene/chitosan-modified GCE for the electrochemical oxidation of NADH. The results showed that the graphene could decrease the overpotential of NADH oxidation on the electrode surface, and that the IL is helpful for the process as well. A good linearity from 0.25 to $2 \mathrm{mM}$ and a high sensitivity of $37.43 \mu \mathrm{A} \mathrm{mM}{ }^{-1} \mathrm{~cm}^{-2}$ were realized. Simultaneously, IL-graphene/ chitosan/alcohol dehydrogenase/GCE was also constructed to detect the alcohol. The asprepared biosensor exhibited a linear range from 25 to $200 \mu \mathrm{M}$ with a good sensitivity of $6.91 \mathrm{nA} \mu \mathrm{M}^{-1} \mathrm{~cm}^{-2}$. Zhang et al. ${ }^{(185)}$ synthesized polymeric IL (PIL) functionalized graphene immobilizing GOD for the detection of glucose. The results demonstrated that the direct electron transfer between the immobilized GOD and the electrode surface could be efficiently achieved owing to the synergistic effects of the conductive graphene and biocompatible PIL. Moreover, the PIL played an important role in stabilizing the modified graphene nanosheets. ${ }^{(187)}$ The as-prepared electrode displayed an excellent sensitivity of $0.767 \mathrm{~A} \mathrm{~cm}^{-2} \mathrm{mM}^{-1}$, a detection limit of $0.267 \mathrm{mM}$, a wide linear range and superb stability. Yang et al. ${ }^{(188)}$ synthesized chemically modified graphene (CMG) and an IL-modified Au electrode for loading the GOD to detect glucose. The fabricated GOD/ CMG-IL/Au electrode displayed a sensitivity of $0.64 \mathrm{~mA} \mathrm{mM}^{-1}$, a detection limit of 0.376 $\mathrm{mM}$, and a response time of $<5 \mathrm{~s}$. Additionally, the IL-graphene nanocomposite as an electrochemical biosensor was also applied to detect cytochrome $\mathrm{c}$ and nitric oxide. ${ }^{(189)}$

Boronic acid derivatives are likely candidates to replace the glucose sensor based on various enzymes because they can preferentially bind with vicinal diols via cyclic ester bond formation. ${ }^{(190)}$ Wang et al. ${ }^{(191)}$ used an RGO-aminophenyl boronic acid hybrid material to directly detect sugars, such as fructose, mannose and glucose, with high sensitivity without any enzyme by differential pulse voltammetry. The fabricated 
sensor exhibited a wide linear range with detection limits of $100 \mathrm{nM}$ for fructose and approximately $800 \mathrm{nM}$ for mannose and glucose.

Table 2

Summary of all nanomaterials applied to construct graphene-based electrochemical biosensors mentioned in this review.

\begin{tabular}{|c|c|c|c|c|}
\hline \multicolumn{3}{|c|}{ Nanomaterial composites with GR } & \multirow{2}{*}{$\begin{array}{l}\text { Analytes } \\
\text { para-nitrophenol, } \\
\text { DNA, NO, } \mathrm{H}_{2} \mathrm{O}_{2}\end{array}$} & \multirow{4}{*}{$\begin{array}{l}\text { Main roles } \\
\text { Load bioelements, } \\
\text { prevent aggregation of } \\
\text { GR, facilitate electron } \\
\text { transfer }\end{array}$} \\
\hline \multirow[t]{10}{*}{ Inorganic materials } & \multirow[t]{3}{*}{ Noble metal } & $\mathrm{Au}$ & & \\
\hline & & $\mathrm{Pt}$ & TNT, $\mathrm{H}_{2} \mathrm{O}_{2}$ & \\
\hline & & $\mathrm{Pd}$ & Cholesterol & \\
\hline & Transition metal & $\mathrm{Ni}$ & Glucose & \\
\hline & \multirow[t]{5}{*}{ Metal oxide } & $\mathrm{Cu}_{2} \mathrm{O}$ & Glucose, $\mathrm{H}_{2} \mathrm{O}_{2}$ & \multirow{5}{*}{$\begin{array}{l}\text { Load bioelements, } \\
\text { prevent aggregation } \\
\text { of GR, act as labels or } \\
\text { tracers }\end{array}$} \\
\hline & & $\mathrm{CuO}$ & Glucose & \\
\hline & & $\mathrm{ZnO}$ & $\mathrm{H}_{2} \mathrm{O}_{2}$ & \\
\hline & & $\mathrm{SnO}_{2}$ & $\mathrm{ATCl}$ & \\
\hline & & $\mathrm{TiO}_{2}$ & $\begin{array}{l}\text { Glucose, DNA, } \\
\text { paracetamol, } \\
\text { carbaryl, base pairs }\end{array}$ & \\
\hline & Inorganic dye & PB & $\mathrm{N}_{2} \mathrm{H}_{4}, \mathrm{H}_{2} \mathrm{O}_{2}, \mathrm{DNA}$ & $\begin{array}{l}\text { Improve electrocatalytic } \\
\text { activity }\end{array}$ \\
\hline \multirow[t]{10}{*}{ Organic materials } & \multirow[t]{4}{*}{ Polymer } & PANI & DA, $\mathrm{H}_{2}$ & \multirow{4}{*}{$\begin{array}{l}\text { Improve solubility/ } \\
\text { processability of GR, } \\
\text { prevent aggregation, } \\
\text { assist biorecognition } \\
\text { formation }\end{array}$} \\
\hline & & TH & AFP & \\
\hline & & PPy & Tryptamine & \\
\hline & & $\mathrm{CS}$ & Glucose, $\mathrm{H}_{2} \mathrm{O}_{2}$ & \\
\hline & \multirow[t]{3}{*}{ Organic dye } & Porphyrin & $\begin{array}{l}\text { Chlorite, DA, } \mathrm{O}_{2} \text {, } \\
\text { ATP, DNA }\end{array}$ & \multirow{3}{*}{$\begin{array}{l}\text { Improve electroactive } \\
\text { properties and dispersity } \\
\text { of GR }\end{array}$} \\
\hline & & MB & PSA, NADH & \\
\hline & & MG & NADH & \\
\hline & \multirow[t]{3}{*}{ Biomolecule } & Enzyme & OPs, glucose, & \multirow{3}{*}{$\begin{array}{l}\text { Produce high-specificity } \\
\text { interaction }\end{array}$} \\
\hline & & Aptamer & Cancer cells & \\
\hline & & Cell & Cellular secretion & \\
\hline \multirow[t]{2}{*}{ Other materials } & Ionic liquids & & $\begin{array}{l}\text { NADH, alcohol, } \\
\text { glucose, NO }\end{array}$ & \multirow{2}{*}{$\begin{array}{l}\text { Prevent irreversible } \\
\text { agglomeration and } \\
\text { guarantee stability or } \\
\text { catalytic activity of GR }\end{array}$} \\
\hline & \multicolumn{2}{|c|}{ Boronic acid derivatives } & $\begin{array}{l}\text { Fructose, mannose } \\
\text { or glucose }\end{array}$ & \\
\hline
\end{tabular}

Abbreviations: GR, graphene; TNT, 2,4,6-trinitrotoluene; ATCl, acetylthiocholine chloride; PB, Prussian Blue; DA, dopamine; PANI, polyaniline; TH, thionine; AFP, fetoprotein; PPy, polypyrrole; CS, chitosan; $\mathrm{Hb}$, hemoglobin protein; ATP, adenosine triphosphate; MB, methylene blue; PSA, prostate-specific antigen; NADH, $\beta$-nicotinamide adenine dinucleotide; MG, methylene green; OPs, organophosphates. 


\section{Conclusions and Outlook}

It is clear that the many excellent characteristics of graphene have caused the explosive growth in work related to the use of graphene-based electrodes for electrochemical biosensors. In this review, the entire outline of recent advances and every type of nanomaterial applied in graphene-based electrochemical biosensors are presented and illustrated in detail (Table 2). From a long-term view, one point for sure is that the thinnest two-dimensional nanomaterials, such as graphene, inorganic graphene analogues, and their combination with other nanomaterials with different morphologies, will still play an important role in electrochemical biosensors owing to their sensitive surfaces state and other advantages. Moreover, novel biological techniques applied in the surface architicture for recognition elements are also powerful tools for electrochemical biosensors.

\section{Acknowledgements}

This study was supported by the National Basic Research Program of China (No. 2013CB430403), National Natural Science Foundation of China (No. 21277016), and Research Project of the Chinese Ministry of Education (No. 113017A).

\section{References}

1 X. Huang, Z. Zeng, Z. Fan, J. Liu and H. Zhang: Adv. Mater. 24 (2012) 5979.

2 A. K. Geim and A. H. MacDonald: Phys. Today 60 (2007) 35.

3 P. S. Sharma, F. D. Souza and W. Kutner: Top Curr. Chem. 128 (2013).

4 M. Zhou and S. J. Dong: Anal. Chem. 81 (2009) 5603.

5 K. S. Novoselov, V. I. Fal'ko, L. Colombo, P. R. Gellert, M. G. Schwab and K. Kim: Nature 490 (2012) 192.

6 H. K. Chae, D. Y. Siberio-Perez, J. Kim and Y. B. Go: Nature 427 (2004) 523.

7 C. Lee, X. Wei, J. W. Kysar and J. Hone: Science 321 (2008) 385.

8 A. A. Balandin, S. Ghosh, W. Z. Bao, I. Calizo, D. Teweldebrhan, F. Miao and C. N. Lau: Nano Lett. 8 (2008) 902.

9 A. S. Mayorov, R. V. Gorbachev, S. V. Morozov, L. Britnell, R. Jalil, L. A. Ponomarenko, P. Blake, K. S. Novoselov, K. Watanabe, T. Taniguchi and A. K. Geim: Nano Lett. 11 (2011) 2396.

10 K. S. Novoselov, A. K. Geim, S. V. Morozov, D. Jiang, Y. Zhang, S. V. Dubonos, I. V. Grigorieva and A. A. Firsov: Science 306 (2004) 666.

11 K. S. Novoselov, A. K. Geim, S. V. Morozov, D. Jiang, M. I. Katsnelson, I. V. Grigorieva, S. V. Dubonos and A. A. Firsov: Nature 438 (2005) 197.

12 S. Gilje, S. Han, M. Wang, K. L. Wang and R. B. Kaner: Nano Lett. 7 (2007) 3394.

13 V. Barone, O. Hod and G. E. Scuseria: Nano Lett. 6 (2006) 2748.

14 Y. Zhang, Y. W. Tan, H. L. Stormer and P. Kim: Nature 438 (2005) 201.

15 M. S. Artiles, C. S. Rout and T. S. Fisher: Adv. Drug Deliv. Rev. 63 (2011) 1352.

16 A. J. Du, Z. H. Zhu and S. C. Smith: J. Am. Chem. Soc. 132 ( 2010$) 2876$.

17 H. Y. Chen and J. Appenzeller: Nano Lett. 12 (2012) 2067.

18 Y. Wu, K. A. Jenkins, A. Valdes-Garcia, D. B. Farmer, Y. Zhu, A. A. Bol, C. Dimitrakopoulos, W. Zhu, F. Xia, P. Avouris and Y. M. Lin: Nano Lett. 12 (2012) 3062. 
19 J. Hou, Y. Shao, M. W. Ellis, R. B. Moore and B. Yi: Phys. Chem. Chem. Phys. 13 (2011) 15384.

20 C. G. Liu, Z. L. Yu, D. Neff, A. Zhamu and B. Z. Jang: Nano Lett. 10 (2010) 4863.

21 C. K. Huang, Y. Ou, Y. Bie, Q. Zhao and D. Yu: Appl. Phys. Lett. 98 (2011) 263104.

22 S. W. Lee, S. S. Lee and E. H. Yang: Nanoscale Res. Lett. 4 (2009) 1218.

23 J. K. Wassei and R. B. Kaner: Mater. Today 13 (2010) 52.

24 Y. Liu, J. Zhou, X. Zhang, Z. Liu, X. Wan, J. Tian, T. Wang and Y. Chen: Carbon 47 (2009) 3113.

25 H. Bai, C. Li and G. Shi: Adv. Mater. 23 (2011) 1089.

26 S. Stankovich, D. A. Dikin, G. H. Dommett, K. M. Kohlhaas, E. J. Zimney, E. A. Stach, R. D. Piner, S. T. Nguyen and R. S. Ruoff: Nature 442 (2006) 282.

27 T. Gan and S. Hu: Microchim. Acta 175 (2011) 1.

28 Y. Fang and E. Wang: Chem. Commun. 49 (2013) 9526.

29 T. Kuila, S. Bose, P. Khanra, A. K. Mishra, N. H. Kim and J. H. Lee: Biosens. Bioelectron. 26 (2011) 4637.

30 Y. Shao, J. Wang, H. Wu, J. Liu, I. A. Aksay and Y. Lin: Electroanal. 22 (2010) 1027.

31 M. Pumera: Mater. Today 14 (2011) 308.

32 M. Pumera, A. Ambrosi, A. Bonanni, E. L. K. Chng and H. L. Poh: TrAC, Trends Anal. Chem. 29 (2010) 954.

33 H. L. Poh, F. Sanek, A. Ambrosi, G. Zhao, Z. Sofer and M. Pumera: Nanoscale 4 (2012) 3515.

34 M. Taghioskoui: Mater. Today 12 ( 2009) 34.

35 A. H. Castro Neto, N. M. R. Peres, K. S. Novoselov and A. K. Geim: Rev. Mod. Phys. 81 (2009) 109.

36 S. Stankovich, D. A. Dikin, R. D. Piner, K. A. Kohlhaas, A. Kleinhammes, Y. Jia, Y. Wu, S. T. Nguyen and R. S. Ruoff: Carbon 45 (2007) 1558.

37 P. W. Sutter, J. I. Flege and E. A. Sutter: Nat. Mater. 7 (2008) 406.

38 Y. Hernandez, V. Nicolosi, M. Lotya, F. M. Blighe, Z. Sun, S. De, I. T. McGovern, B. Holland, M. Byrne, Y.K. Gun'Ko, J. J. Boland, P. Niraj, G. Duesberg, S. Krishnamurthy, R. Goodhue, J. Hutchison, V. Scardaci, A. C. Ferrari and J. N. Coleman: Nat. Nanotechnol. 3 (2008) 563.

39 K. S. Kim, Y. Zhao, H. Jang, S.Y. Lee, J. M. Kim, K. S. Kim, J. H. Ahn, P. Kim, J. Y. Choi and B. H. Hong: Nature 457 (2009) 706.

40 M. Choucair, P. Thordarson and J. A. Stride: Nat. Nanotechnol. 4 (2009) 30.

41 Y. Zhu, S. Murali, W. Cai, X. Li, J. W. Suk, J. R. Potts and R. S. Ruoff: Adv. Mater. 22 (2010) 3906.

42 C. Soldano, A. Mahmood and E. Dujardin: Carbon 48 (2010) 2127.

43 Y. C. Si and E. T. Samulski: Nano Lett. 8 (2008) 1679.

44 A. Guo, Y. Li, W. Cao, X. Meng, D. Wu, Q. Wei and B. Du: Biosens. Bioelectron. 63 (2015) 39.

45 P. S. Sharma, F. D.Souza and W. Kutner: Top Curr. Chem. 348 (2014) 237.

46 R. L. McCreery: Chem. Rev. 108 (2008) 2646.

47 C. E. Banks, T. J. Davies, G. G. Wildgoose and R. G. Compton: Chem. Commun. 7 (2005) 829.

48 I. Dumitrescu, P. R. Unwin and J. V. Macpherson: Chem. Commun. 45 (2009) 6886.

49 J. Wang: Electroanal. 17 (2005) 7.

50 N. J. Ronkainen, H. B. Halsall and W. R. Heineman: Chem. Soc. Rev. 39 (2010) 1747.

51 D. Marazuela and M. C. Moreno-Bondi: Anal. Bioanal. Chem. 372 (2002) 664.

52 A. P. F. Turner: Chem. Soc. Rev. 42 (2013) 3184.

53 Y. Miyake, H. Togashi, M. Tashiro, H. Yamaguchi, S. Oda, M. Kudo, Y. Tanaka, Y. Kondo, R. Sawa, T. Fujimoto, T. Machinami and A. Ono: J. Am. Chem. Soc. 128 (2006) 2172. 
54 Z. Lin, X. Li and H. B. Kraatz: Anal. Chem. 83 (2011) 6896.

55 D. Wu, Q. Zhang, X. Chu, H. Wang, G. Shen and R. Yu: Biosens. Bioelectron. 25 (2010) 1025 .

56 O. Domínguez-Renedo, M. A. Alonso-Lomillo, L. Ferreira-Gonçalves and M. J. ArcosMartínez: Talanta 79 (2009) 1306.

57 Y. Zhang, H. Zhao, Z. Wu, Y. Xue, X. Zhang, Y. He, X. Li and Z. Yuan: Biosens. Bioelectron. 48 (2013) 180.

58 Q. Xu, L. Cai, H. Zhao, J. Tang, Y. Shen, X. Hu and H. Zeng: Biosens. Bioelectron. 63 (2015) 294.

59 D. Wei, M. J. Bailey, P. Andrew and T. Ryhanen: Lab Chip 9 (2009) 2123.

60 K. T. Daniel R. Thévenot, R. A. Durst and G. S. Wilson: Biosens. Bioelectron. 16 ( 2001) 121.

61 Z. Zhang, A. Tang, S. Liao, P. Chen, Z. Wu, G. Shen and R. Yu: Biosens. Bioelectron. 26 (2011) 3320 .

62 R. M. Kong, X. B. Zhang, L. L. Zhang, X. Y. Jin, S. Y. Huan, G. L. Shen and R. Q. Yu: Chem. Commun. 37 (2009) 5633.

63 T. Asefa, C. T. Duncan and K. K. Sharma: Analyst 134 (2009) 1980.

64 J. M. Pingarrón, P. Yáñez-Sedeño and A. González-Cortés: Electrochim. Acta 53 (2008) 5848.

65 L. Chen, H. Xie and J. Li: J. Solid State Electr. 16 (2012) 3323.

66 S. Cao, L. Zhang, Y. Chai and R. Yuan: Talanta 109 (2013) 167.

67 Z. Chang, H. Fan, K. Zhao, M. Chen and P. He, Y. Fang: Electroanal. 20 (2008) 131.

68 F. Xiao, F. Zhao, D. Mei, Z. Mo and B. Zeng: Biosens. Bioelectron. 24 (2009) 3481.

69 A. Ata Saei, J. E. Nazhad Dolatabadi, P. Najafi-Marandi, A. Abhari and M. de la Guardia: TrAC, Trends Anal. Chem. 42 (2013) 216.

70 J. Wang: Microchim. Acta 177 (2012) 245.

71 S. Guo and S. Dong: TrAC, Trends Anal. Chem. 28 (2009) 96.

72 W. Putzbach and N. J. Ronkainen: Sensors 13 (2013) 4811.

73 Y. Li, H. J. Schluesener and S. Q. Xu: Gold Bulletin 43 (2010) 29.

74 Y. Zhang and W. Jiang: Electrochim. Acta 71 (2012) 239.

75 M. Q. Xu, J. F. Wu and G. C. Zhao: Sensors 13 (2013) 7492.

76 K. J. Huang, D. J. Niu, X. Liu, Z. W. Wu, Y. Fan, Y. F. Chang and Y. Y. Wu: Electrochim. Acta 56 (2011) 2947.

77 W. Zhang, J. Chang, J. Chen, F. Xu, F. Wang, K. Jiang and Z. Gao: Res. Chem. Intermediat. 38 (2012) 2443.

78 S. J. Guo, Y. M. Zhai, S. J. Dong and Er. K. Wang: ACS Nano 4 (2010) 3959.

79 Q. Zeng, J. S. Cheng, X. F. Liu, H. T. Bai and J. H. Jiang: Biosens. Bioelectron. 26 (2011) 3456.

80 B. Su, J. Tang, H. Yang, G. Chen, J. Huang and D. Tang: Electroanal. 23 (2011) 832.

81 M. Rauber, F. Muench, M. E. Toimil-Molares and W. Ensinger: Nanotechnology 23 (2012) 475710 .

82 T. Cohen-Karni, Q. Qing, Q. Li, Y. Fang and C. M. Lieber: Nano Lett. 10 (2010) 1098.

83 S. M. C. Umasankar Yogeswaran: Sensors 8 (2008) 290.

84 S. Aravamudhan, N. Ramgir and S. Bhansali: Sens. Actuators, B 127 (2007) 29.

85 L. Yang, Y. Zhang, M. Chu, W. Deng, Y. Tan, M. Ma, X. Su, Q. Xie and S. Yao: Biosens. Bioelectron. 52 (2014) 105.

86 B. He, T. J. Morrow and C. D. Keating: Curr. Opin. Chem. Biol. 12 (2008) 522.

87 Q. Wang, F. Min and J. Zhu: Mater. Lett. 91 (2013) 9.

88 D. Lee, H. Lee, Y. Ahn, Y. Jeong, D. Y. Lee and Y. Lee: Nanoscale 5 (2013) 7750. 
89 H. W. Tien, S. T. Hsiao, W. H. Liao, Y. H. Yu, F. C. Lin, Y. S. Wang, S. M. Li and C. C. M. Ma: Carbon 58 (2013) 198.

90 Z. Wang, Y. Hu, W. Yang, M. Zhou and X. Hu: Sensors 12 (2012) 4860.

91 Y. Zhang, X. Xiao, Y. Sun, Y. Shi, H. Dai, P. Ni, J. Hu, Z. Li, Y. Song and L. Wang: Electroanal. 25 (2013) 959.

92 S. L. P. Poizot, S. Grugeon and L. Dupont: Nature 407 ( 2000) 496.

93 P. R. Solanki, A. Kaushik, V. V. Agrawal and B. D. Malhotra: NPG Asia Mater. 3 (2011) 17.

94 S. K. Mahadeva and J. Kim: Sens. Actuators, B 157 (2011) 177.

95 K. Wang, H. N. Li, J. Wu, C. Ju, J. J. Yan, Q. Liu and B. Qiu: Analyst 136 (2011) 3349.

96 Y. Fan, H. T. Lu, J. H. Liu, C. P. Yang, Q. S. Jing, Y. X. Zhang, X. K. Yang and K. J. Huang: Colloids Surf. B Biointerfaces 83 (2011) 78.

97 A. T. L. Wang, S. E. Pratsinis and P. I. Gouma: Chem. Mater. 20 (2008) 4794.

98 S. K. Arya, S. Saha, J. E. Ramirez-Vick, V. Gupta, S. Bhansali and S. P. Singh: Anal. Chim. Acta 737 (2012) 1.

99 M.S. Lin and H. J. Leu: Electroanal. 17 (2005) 2068.

100 H. Jiang, J. Hu, F. Gu, W. Shao and C. Li: Chem. Commun. 24 (2009) 3618.

101 Y. H. Bai, Y. Du, J. J. Xu and H. Y. Chen: Electrochem. Commun. 9 (2007) 2611.

102 Y. Fan, L. Wang, J. Li, J. Li, S. Sun, F. Chen, L. Chen and W. Jiang: Carbon 48 (2010) 1743.

103 A. Salimi, R. Hallaj and S. Soltanian: Electroanal. 21 (2009) 2693.

104 Y. Mu, D. Jia, Y. He, Y. Miao and H. L. Wu: Biosens. Bioelectron. 26 (2011) 2948.

105 C. L. Sun, W. L. Cheng, T. K. Hsu, C. W. Chang, J. L. Chang and J. M. Zen: Electrochem. Commun. 30 (2013) 91.

106 F. Xu, M. Deng, G. Li, S. Chen and L. Wang: Electrochim. Acta 88 (2013) 59.

107 G. Korotcenkov, B. K. Cho, L. Gulina and V. Tolstoy: Sens. Actuators, B 138 (2009) 512.

108 Y. Zhu, X. Su, C. Yang, X. Gao, F. Xiao and J. Wang: J. Mater. Chem. 22 (2012) 13914.

109 M. Liu, R. Liu and W. Chen: Biosens. Bioelectron. 45 (2013) 206.

110 Y. W. Hsu, T. K. Hsu, C. L. Sun, Y. T. Nien, N. W. Pu and M. D. Ger: Electrochim. Acta 82 (2012) 152.

111 X. Lu, H. Zhang, Y. Ni, Q. Zhang and J. Chen: Biosens. Bioelectron. 24 (2008) 93.

112 L. Xie, Y. Xu and X. Cao: Colloids Surf. B Biointerfaces 107 (2013) 245.

113 J. Xu, C. Liu and Z. Wu: Microchimica Acta 172 (2010) 425.

114 A. Fuchs, H. J. Schimper, A. Klein and W. Jaegermann: Energy Procedia 10 (2011) 149.

115 S. B. Patil, P. P. Patil and M. A. More: Sens. Actuators, B 125 (2007) 126.

116 D. Chu, Y. Masuda, T. Ohji and K. Kato: Chem. Eng. J. 168 (2011) 955.

117 H. Kim, S. W. Kim, Y. U. Park, H. Gwon, D. H. Seo, Y. Kim and K. Kang: Nano Res. 3 (2010) 813.

118 Q. Zhou, L. Yang, G. Wang and Y. Yang: Biosens. Bioelectron. 49 (2013) 25.

119 H. D. Jang, S. K. Kim, H. Chang, K. M. Roh, J. W. Choi and J. Huang: Biosens. Bioelectron. 38 (2012) 184

120 H. Gao, M. Sun, C. Lin and S. Wang: Electroanal. 24 (2012) 2283.

121 Y. Fan, K. J. Huang, D. J. Niu, C. P. Yang and Q. S. Jing: Electrochim. Acta 56 (2011) 4685.

122 F. Ricci and G. Palleschi: Biosens. Bioelectron. 21 (2005) 389.

123 Y. Jiang, X. Zhang, C. Shan, S. Hua, Q. Zhang, X. Bai, L. Dan and L. Niu: Talanta 85 (2011) 76.

124 E. Jin, X. Lu, L. Cui, D. Chao and C. Wang: Electrochim. Acta 55 (2010) 7230.

125 Y. Bo, W. Wang, J. Qi and S. Huang: Analyst 136 (2011) 1946.

126 R Garjonyte and A. Malinauskas: Sens. Actuators, B 56 (1999) 93.

127 Y. Xu, Z. Liu, X. Zhang, Y. Wang, J. Tian, Y. Huang, Y. Ma, X. Zhang and Y. Chen: Adv. Mater. 21 (2009) 1275. 
128 Y. Hu, K. Wang, Q. Zhang, F. Li, T. Wu and L. Niu: Biomaterials 33 (2012) 1097.

129 M. Gerard, A. Chaubey and B. D. Malhotra: Biosens. Bioelectron. 17 (2002) 345.

130 U. Lange, N. V. Roznyatovskaya and V. M. Mirsky: Anal. Chim. Acta 614 (2008) 1.

131 B. Adhikari and S. Majumdar: Prog. Polym. Sci. 29 (2004) 699.

132 J. R. Stetter: Chem. Rev. 108 (2008) 352.

133 T. Ahuja, I. A. Mir, D. Kumar and Rajesh: Biomaterials 28 (2007) 791.

134 P. C. Pandey, G. Singh and P. K. Srivastava: Electroanal. 14 (2002) 427.

135 A. Rahman; M. S. Won and Y. B. Shim: Anal. Chem. 75 (2003) 1123.

136 J. Zhang, Y. Wang, R. Lv and L. Xu: Electrochim. Acta 55 (2010) 4039.

137 S. Liu, X. Xing, J. Yu, W. Lian, J. Li, M. Cui and J. Huang: Biosens. Bioelectron. 36 (2012) 186.

138 L. Al-Mashat, K. Kalantar-Zadeh, J. D. Plessis, S. H. Han, R. W. Kojima, R. B. Kaner, D. Li, X. L. Gou, S. J. Ippolito and W. Wlodarski: J. Phys. Chem. C 114 (2010) 16168.

139 Y. Bo, H. Yang, Y. Hu, T. Yao and S. Huang: Electrochim. Acta 56 (2011) 2676.

140 Q. Wei, K. Mao, D. Wu, Y. Dai, J. Yang, B. Du, M. Yang and H. Li: Sens. Actuators, B 149 (2010) 314.

141 X. Xing, S. Liu, J. Yu, W. Lian and J. Huang: Biosens. Bioelectron. 31 (2012) 277.

142 M. Rinaudo: Prog. Polym. Sci. 31 (2006) 603.

143 X. Kang, J. Wang, H. Wu, I.A. Aksay, J. Liu and Y. Lin: Biosens. Bioelectron. 25 (2009) 901.

144 H. Xu, H. Dai and G. Chen: Talanta 81 (2010) 334.

145 X. Qi, H. Gao, Y. Zhang, X. Wang, Y. Chen and W. Sun: Bioelectrochemistry 88 (2012) 42.

146 H. Wu, J. Wang, X. Kang, C. Wang, D. Wang, J. Liu, I.A. Aksay and Y. Lin: Talanta 80 (2009) 403.

147 K. Zhou, Y. Zhu, X. Yang, J. Luo, C. Li and S. Luan: Electrochim. Acta 55 (2010) 3055.

148 H. Yin, Y. Zhou, Q. Ma, S. Ai, Q. Chen and L. Zhu: Talanta 82 (2010) 1193.

149 Y. Qiu, X. Qu, J. Dong, S. Ai and R. Han: J. Hazard. Mater. 190 (2011) 480.

150 H. Li, J. Chen, S. Han, W. Niu, X. Liu and G. Xu: Talanta 79 (2009) 165.

151 Y. Fan, J.H. Liu, H.T. Lu and Q. Zhang: Colloids Surf. B Biointerfaces 85 (2011) 289.

152 D. Li, M. B. Muller, S. Gilje, R. B. Kaner and G. G. Wallace: Nat. Nanotechnol. 3 (2008) 101.

153 A. Ghosh, K. V. Rao, S. J. George and C. N. Rao: Chemistry 16 (2010) 2700.

154 J. Li, S. Guo, Y. Zhai and E. Wang: Anal. Chim. Acta 649 (2009) 196.

155 H. Yin, Y. Zhou, Q. Ma, S. Ai, P. Ju, L. Zhu and L. Lu: Process Biochem. 45 (2010) 1707.

156 W. Tu, J. Lei, S. Zhang and H. Ju: Chemistry 16 (2010) 10771.

157 L. Wu, L. Feng, J. Ren and X. Qu: Biosens. Bioelectron. 34 (2012) 57.

158 S. Zhang, S. Tang, J. Lei, H. Dong and H. Ju: J. Electroanal. Chem. 656 (2011) 285.

159 Q. Wang, J. Lei, S. Deng, L. Zhang and H. Ju: Chem. Commun. 49 (2013) 916.

160 H. Zhang, Y. Han, Y. Guo and C. Dong: J. Mater. Chem. 22 (2012) 23900.

161 M. Liu, C. Luo and H. Peng: Talanta 88 (2012) 216.

162 S. O. Kelley, J. K. Barton, N. M. Jackson and M. G Hill: Bioconjugate Chem. 8 (1997) 31.

163 E. M. Boon, N. M. Jackson, M. D. Wightman, S. O. Kelley, M. G. Hill and J. K. Barton: J. Phys. Chem. B 107 (2003) 11805.

164 P. Kara, K. Kerman, D. Ozkan, B. Meric, A. Erdem, P. E. Nielsen and M. Ozsoz: Electroanal. 14 (2002) 1685.

165 K. Mao, D. Wu, Y. Li, H. Ma, Z. Ni, H. Yu, C. Luo, Q. Wei and B. Du: Anal. Biochem. 422 (2012) 22.

166 G. M. M. Ferreira, F. M. de Oliveira, F. R. F. Leite, C. M. Maroneze, L. T. Kubota, F. S. Damos and R. D. S. Luz: Electrochim. Acta 111 (2013) 543.

167 H. Liu, J. Gao, M. Xue, N. Zhu, M. Zhang and T. Cao: Langmuir 25 (2009) 12006.

168 H.Y. C. Shan, J. Song and D. Han: Anal. Chem. 81 (2009) 2378. 
169 S. M. Chen and S. V. Chen: Electrochim. Acta 48 (2003) 513.

170 H. V. Tran, B. Piro, S. Reisberg, H. T. Duc and M. C. Pham: Anal. Chem. 85 (2013) 8469.

171 S. Song, L. Wang, J. Li, C. Fan and J. Zhao: TrAC, Trends Anal. Chem. 27 (2008) 108.

172 L. Feng, Y. Chen, J. Ren and X. Qu: Biomaterials 32 (2011) 2930.

173 B. Pérez-López and A. Merkoçi: Trends Food Sci. Tech. 22 (2011) 625.

174 T. Liu, M. Xu, H. Yin, S. Ai, X. Qu and S. Zong: Microchim. Acta 175 (2011) 129.

175 P. Wu, Q. Shao, Y. Hu, J. Jin, Y. Yin, H. Zhang and C. Cai: Electrochim. Acta 55 (2010) 8606.

176 S. Palanisamy, A. T. E. Vilian and S. M. Chen: Int. J. Electrochem. Sci. 7 (2012) 2153.

177 K. Wang, Q. Liu, L. Dai, J. Yan, C. Ju, B. Qiu and X. Wu: Anal. Chim. Acta 695 (2011) 84.

178 A. Erdem: Talanta 74 (2007) 318.

179 T. Premkumar and K. E. Geckeler: Prog. Polym. Sci. 37 (2012) 515.

180 P. Nguyen and V. Berry: J. Phys. Chem. Lett. 3 (2012) 1024.

181 L. H. Hess, M. Jansen, V. Maybeck, M. V. Hauf, M. Seifert, M. Stutzmann, I. D. Sharp, A. Offenhausser and J. A. Garrido: Adv. Mater. 23 (2011) 5045.

182 Q. Y. He, H. G. Sudibya, Z. Y. Yin, S. X. Wu, H. Li, F. Boey, W. Huang, P. Chen and H. Zhang: ACS Nano 4 (2010) 3201.

183 R. Marcilla, F. Alcaide, H. Sardon, J.A. Pomposo, C. Pozo-Gonzalo and D. Mecerreyes: Electrochem. Commun. 8 (2006) 482.

184 C. Shan, H. Yang, D. Han, Q. Zhang, A. Ivaska and L. Niu: Biosens. Bioelectron. 25 (2010) 1504.

185 Q. Zhang, S. Wu, L. Zhang, J. Lu, F. Verproot, Y. Liu, Z. Xing, J. Li and X. M. Song: Biosens. Bioelectron. 26 (2011) 2632.

186 F. Li, J. Chai, H. Yang, D. Han and L. Niu: Talanta 81 (2010) 1063.

187 H. F. Yang, C. S. Shan, F. H. Li, D. X. Han, Q. X. Zhang and L. Niu: Chem. Commun. 26 (2009) 3880.

188 M. H. Yang, B. G. Choi, H. Park, W. H. Hong, S. Y. Lee and T. J. Park: Electroanal. 22 (2010) 1223.

189 H. Chen and G. Zhao: J. Solid State Electro. 16 (2012) 3289.

190 D. Das, D. M. Kim, D. S. Park and Y. B. Shim: Electroanal. 23 (2011) 2036.

191 Q. Wang, I. Kaminska, J. Niedziolka-Jonsson, M. Opallo, M. Li, R. Boukherroub and S. Szunerits: Biosens. Bioelectron. 50 (2013) 331. 